\title{
AFEHANLSTAN FDRע凹
}

EONTENTS

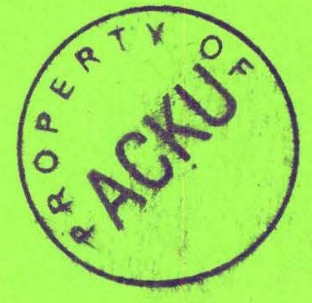

VDL. XH16

ND. 4

July 1985

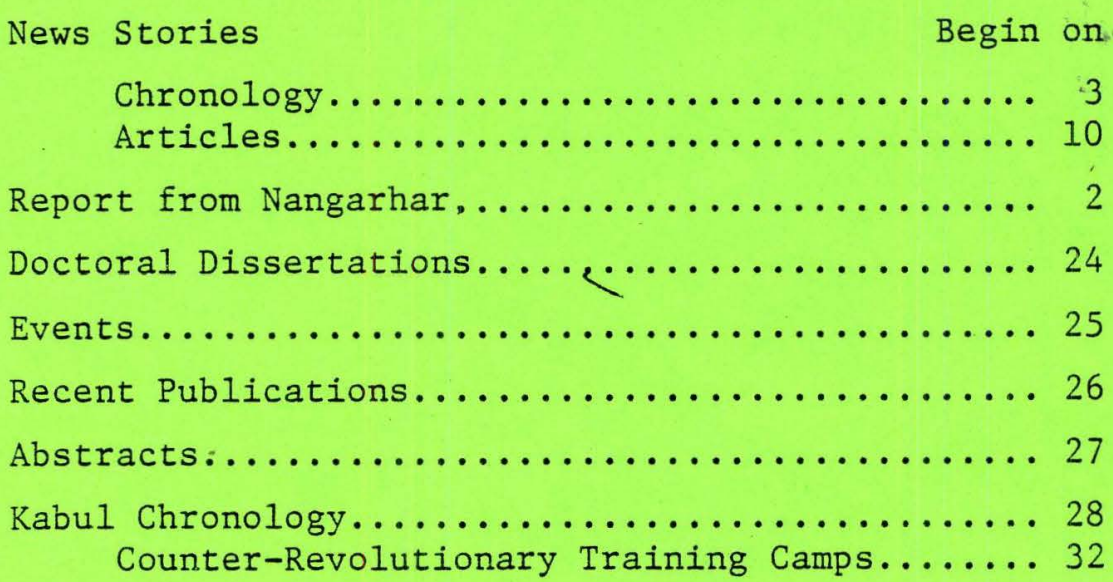

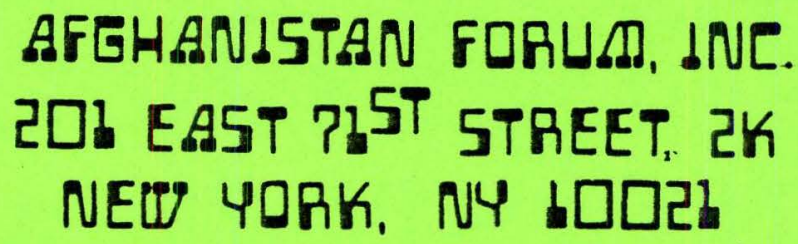



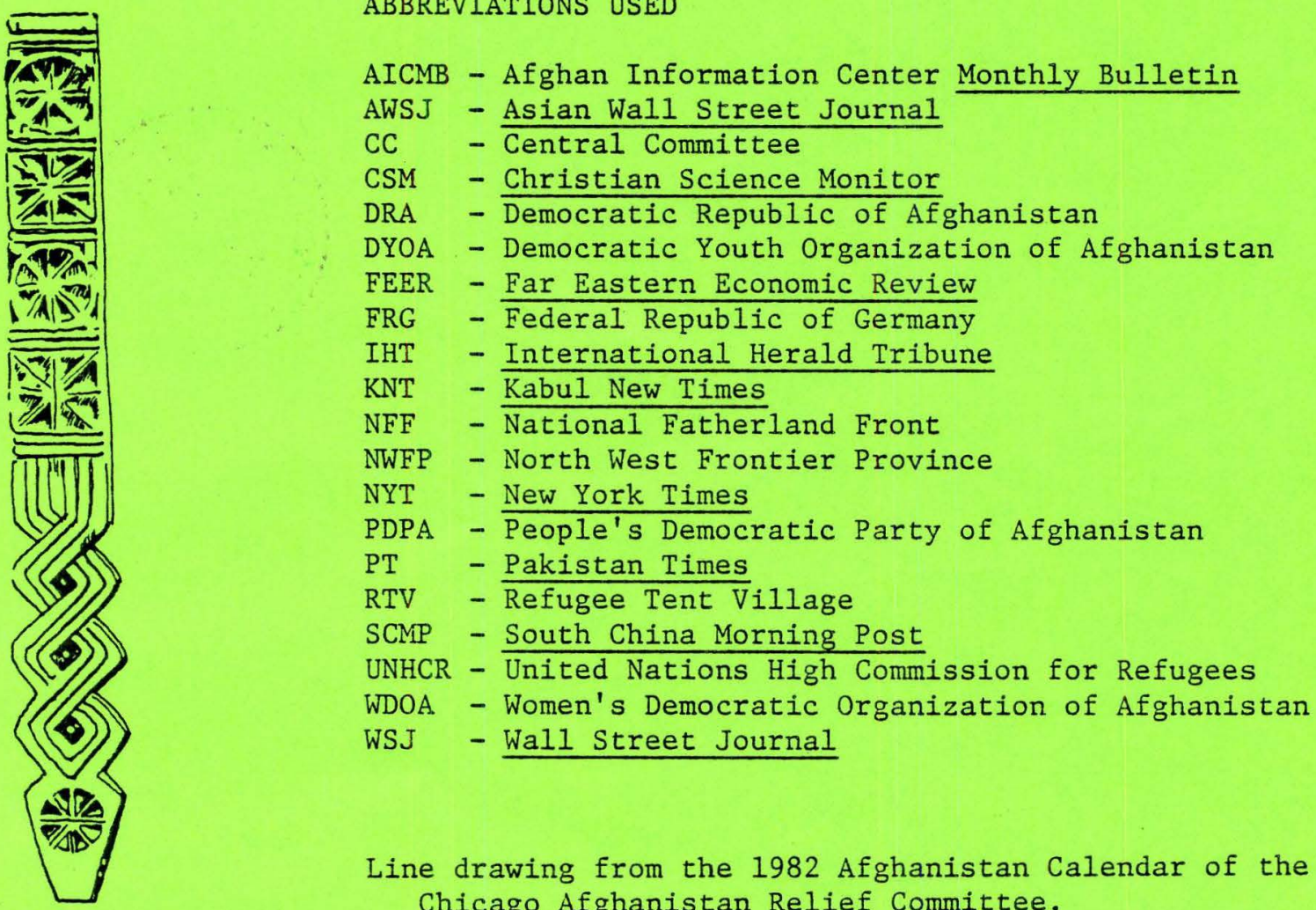

Line drawing from the 1982 Afghanistan Calendar of the Chicago Afghanistan Relief Committee.

Please send items for the AFGHANISTAN FORUM to The Afghanistan Forum, Inc.

201 East 71st Street, 2K

New York, NY 10021, USA

The opinions expressed in the FORUM are those of the parties \& publications involved and are not necessarily those of the Afghanistan FORUM. Listing of organizations does not necessarily imply endorsement.

\footnotetext{
Subscription rates: $\$ 20$ per year (US \& Canada) (Add $\$ 5$ for FORUM PAPERS)

6 issues/year 
From the editor:

We'11 take this opportunity to repeat our all-purpose disclaimer: We include in the FORUM what has been reported about Afghanistan \& Afghans from as many sources as possible. We read \& enjoy everyone's propaganda \& we try to give our readers the cream.

There have been some wonderful rumors lately. For example, "All the Peshawar party leaders are under house arrest in Islamabad." One couldn't find the house they were under arrest in because the leaders were all in Peshawar forming a new alliance.

A more likely rumor is that Amb. Charles Dunbar will become a special adviser on Afghan affairs to the State Department, pending Congressional approval. Still in circulation is the rumor that Sultan Ali Keshtmand is to be Babrak's replacement. Karina Keshtmand is the head of all the kindergartens in the DRA \& Mahbooba Karmal presides over the Watan Nurseries if that gives one any clue to the socialist pecking order. We only bet on sure things - like horses \& state lotteries.

The deadline for the next FORUM is August 15. Send your articles, abstracts, comments suggestions, etc. And if you miss that deadline, the next one is October 15 for the November issue.

We hope that some of the people who have promised book reviews will have them in in time for the next issue.

A good summer to all our readers.
French journalist 01ivier Roy visited the FORUM on June 6 . He gave us his assessment of the situation in Afghanistan.

He stated that the Soviets have not increased their troop numbers in Afghanistan but are now using specially-trained twoyear (not regular army) Russian \& Ukrainian troops. They are deployed in small mobile units \& are adept at night ambushes \& helicopter attacks using infrared equipment.

He said it would not be easy for the Soviets to send in reserves. They might be able to supply another 50,000 but $\frac{1}{4}$ of all soviet paratroopers are already in Afghanistan. He estimated that there were 8,000 Soviet \& 3,000 Afghan soldiers in the Kunar Valley campaign. He thinks the Soviets have reached their peak efficiency level for troops for the next two years and he feels that this period will be extremely important for the mujahideen.

He approves of the new resistance alliance feeling that the people in charge represent those who have the most active internal resistance. The gap between the internal resistance \& the outside is closing. (See p. 24)

He pointed out that the Soviet press is making Afghanistan a very patriotic war, especially among Russians \& Ukrainians not among the Soviet Muslims or other minorities. The press is also cool to Babrak Karmal.

Roy feels that India \& Iran would have accepted an independent communist government in Afghanistan but that the puppet state there now is really too much for them to take. The local Afghan militia is Soviet controlled, he said, but it plays both sides the resistance \& the Babrak regime.

He is more optimistic about the mujahideen's ability to put pressure on the Soviets than other Afghan watchers and he noted the fact that, since Afghanistan, volunteers for the Soviet navy have increased - and the navy is a 3-year hitch!

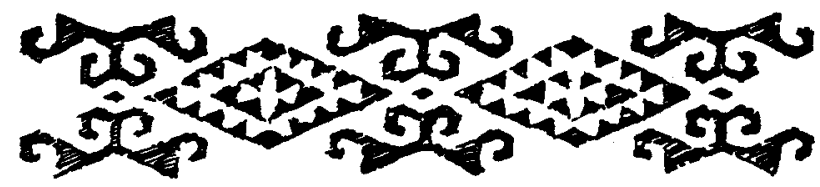


The publication JEHAD-E-AFGHAN (see p. 26) is doing a series on Afghan provinces. Nangarhar (sic) [choose your spelling] is featured in the March issue. Excerpts follow:

Nangrahar (sic) is one of the eastern provinces of Afghanistan which has long mountainous borders with Pakistan. Jalalabad is the capital city situated $147 \mathrm{~km}$ east of Kabul. Nangrahar has an area of $4497 \mathrm{sq.} \mathrm{km}$. and has over 825 villages. Wheat, maize, barley \& poppy are the most common crops. Nangrahar is among those provinces of Afghanistan where the poppy crop is most common. During the time of Zahir Shah \& Daud, most of the opium was exported to Iran with only a little going to Pakistan. Soon after the 1978 coup the opium began flowing to the Pakistan border regions. In view of the financial problems of the local people, mujahideen do not interfere with the free flow of this trade. It is a source of income.

Nangrahar has. 10 districts \& 9 subdistricts. Major tribes living there are Khughiani, Mohmand \& Shinwar with some Ghaljee in the western regions.- The first uprising against King Amanullah started from the Shinwair regions of Nangrahar. Generally speaking, the people are well educated \& Nangrahar was the center of political activity during the final days of Zahir Shah.' After the military coup of July 17 by. Moh'd Daud, many Nangrahar political activists were jailed. Some crossed over into Pakistan to organize themselves with other patriotic Afghans to struggle against Daud. These Islamic forces attacked many divisional \& subdivisional headquarters in Nangrahar; however, no popular uprising occurred.

The communist coup of Taraki caused people everywhere in Afghanistan to reorganize against the infidel government. Popular revolts began in Nangrahar although vast areas of the province were under communist control and the communists had many supporters there. In April 1979, Maulvi Moh'd Yunus Khalis went to Nangrahar with some of his followers. They formed a center in the Wali Naw area near Pacheer \& began launching attaiciss on government targets in south \& western Nangrahar. After the Soviet invasion the resistance became widespread \& much of Nangrahar was liberated.

Currently the jehad is in full swing but the intelligence activity of the Karmal regime has been increased. And a number of prominent commanders who could be helping are sitting idle in Peshawar: At present the mujahideen are well armed in Nangrahar. The government is trying to keep the resistance occupied fighting at remote outposts. Very few attacks are carried out on Jalalabad. The fighting is in the rural areas \& this is what the Russians love. In the past 2 or 3 months the Russians have killed over 200 civilians in Nangrahar. The Russians tend to avoid firing across the Pakistan border but on $3 / 15$, when the resistance forces over ran the Torkham outpost the situation looked dangerous. Red Army troops moved in on the 16th but returned to their bases on the $24 \mathrm{th}$. The Government has established many security posts in the rural areas with a view of keeping the mujahideen engaged. The majority of the people in Nangrahar are with Khalis' Hezb-i-Islami. The 2nd largest group is Hikmatyar's Hezb-i-Islami. Other parties there are Jabha-i-Nejlth-i-Milli (Sayyaf) \& Jamiat-i-Islami. There is no all-out unity; clashes have occurred among the mujahideen. Khad is active in Nangrahar \& several mujahideen commanders have been martyred there.

In JEHAD -E-AFGHAN's opinion the resistance leaders must consider the following points:

1. Khad agents should be pinpointed \& interrogated. Their accomplices should be discovered.

2. Fighting should be concentrated in the cities.

3. There must be unity at least on the local level among mujahideen

4. Command of the jehad should be entrusted to able \& experienced commanders.

The above points can be applied anywhere in the country. If the present condition is allowed to go on we are afraid, God forbid, that the mujahideen will be forced to seek refuge in caves \& mountains. They will not be in a position to beat off the enemy in towns \& cities. 
4/14 - PT - The oil pipeline between Toghundi \& Herat was destroyed by mujahideen bombs; the Soviets then bombed Herat city killing 60 civilians.

4/16 - AICMB \#49 - Maulvi Shafiullah, the commander of Kohi Safi in the Dehsabz district of Kabul, was killed when a Soviet rocket hit the mosque in which he was praying.

- PT - The Indo-Afghan Joint Commission wili hold talks in July in Delhi on future economic \& technical cooperation.

4/21 - PT - Abdur Rashid Khair Khawa, a Jamiat-i-Islami commander in Farah, was killed in a 5-day fight near the Iranian border.

4/22 - PT - Mujahideen destroyed 80 tanks in Samangan during a 10-day battle.

4/25 - PT - DRA Planning Commissioner Sarwar Mengal said in an interview on Moscow Radio that the DRA economy has lost Afs. 37 billion in the struggle with the freedom fighters.

- Extra Soviet troops were brought into Kabul for guard duty during the Loya Jirgah (see below).

4/27 - Hong Kong stiandard - Radio Kabul reported that the Loya Jirgah (see Kabul chron. 4/23 - 5/6) "unveiled a plan to crush anti-gov't rebels by sealing the country's borders \& saying the Soviet Union was ready to provide whatever help was needed." Over 1,600 delegates attended the sessions.

- The AICMB \#49 describes the Jirgah elections: On 4/11 Radio Kabul announced that a Jirgah would be held sometime in 1985. On 4/15 the Radio reported that elections for members of the Jirgah were underway in all provinces. On the 17th elections were announced as successfully ended. The Radio Kabul report from Jalalabad said: "Today the people of Jalalabad held a large meeting in that city. Khodaidad Basharmal, the Southeast Zone Chief, delivered the opening speech... Then in a free \& democratic atmosphere the people elected 82 representatives to the Loya Jirgah."

- HK, Standard - Moh'd Yusof Azim, a senior judge of the Afghan Supreme Court, defected yesterday in Indla with his wife \& 4 children.
4/29 - NYT - One person was killed \& several wounded in a gunfight between 2 Afghan refugee groups in the NWFP. - SCMP - Babrak promoted 9 generals, including the defense \& interior ministers. He also promoted 19 others from colonel to brigadier general.

- PT - A new commission consisting of 21 prominent citizens from different countries has been formed to watch the Afghan situation \& provide humanitarian assistance. Prof. Van Bovan is the president of the new commission.

4/30 - PT - Nangarhar mujahideen reportedly stormed Jalalabad airport last week \& closed it for 2 days.

- NY Tribune - Afghan resistance leaders Amin Wardak, Walid Majrooh \& Omar Sherdil were in Washington last week to lobby for assistance in trying to unseat the DRA government from the UN. The US says the administration is not ready to support such a move because it "would undermine the principle of universality." The US might be willing to support a bid for a special Afghan resistance delegation - like the PLO.

$5 / 1$ - PT - A blast in Kabul at the end of the Jadi Maiwand killed $1 \&$ injured 48 participants in the parade marking the 7 th anniversary of the Saur Revolution. - SCMP - Soviet troops reportedly massacred hundreds of civilians in Laghman, Samangan, Khanabad (Kunduz) \& Herat.

$5 / 2$ - PT - Radio Tehran reports heavy fighting in Herat \& Nimroz.

$5 / 4$ - PT - Mujahideen attacked the Khad headquarters in Mazar-i-Sharif.

5/5 - PT - Mujahideen, led by Amir Humza of Jamiat Islami, attacked a military post in Farah. The Soviets retaliated by shelling Daulatabad.

- The UN Sec'y Gen'1 sent Babrak a congratulatory message on the 7 th anniversary of the Saur Revolution.

- Selig Harrison told Congress that the US had plans to provide the Afghan resistance with Oerlikon $20 \mathrm{~mm}$ anti aircraft cannon \& use air drops by C-130s from China or Oman to supply the mujahideen. He said covert aid to the mujah1deen had jumped 6-fold since 1980. 
$5 / 6$ - HK Standard - Commander Sanagul of the Hizbe Islami reported that 1,200 Cuban commandos were parachuted into Laghman late last month to conduct round-up operations in the Qarghaie district.

5/7 - PT - Burma \& Pakistan reaffirmed their support for a just \& durable settlement of the Afghan issue in a joint communique issued at the end of Zia's visit to Burma.

5/8 - IHT - Pakistan denied that any Soviet prisoners were being held in Pakistan (see Kabul chron. 5/9). It said the incident was between two rival guerrilla groups \& that one man was killed \& several injured when an ammunition dump blew up. Guerrilla sources recently said that prisoners were being held at the camp \& that there had been an escape attempt. The prisoners seized an arsenal \& negotiated with guerrilla leaders for several hours before the guerrillas opened fire, sources said. (Seep.13)

$5 / 9$ - NYT - Mikhail Gorbachev, in a speech marking the 40th anniversary of the defeat of Nazi Germany accused the US of pursuing a more bellicose policy on the int' 1 scene \& a policy of state terrorism in Nicaragua \& Afghanistan.

- Under Sec'y of State Wm. Schneider, $\mathrm{Jr}$ said Congress would be asked to approve $\$ 4 \mathrm{~m}$ for the rest of the current fiscal year \& $\$ 5 \mathrm{~m}$ for 1986 for aid to Afghan rebel groups. The $\$ 4 \mathrm{~m}$ would be for food \& medical help \& would be administered by AID.

5/10 - PT - The Voice of Germany said that the USSR has installed Frog-7 surface-to-surface missiles outside Kabul. The missiles have a $70 \mathrm{~km}$ range.

$5 / 11$ - SCMP - Ending a visit to South Korea, Pak. Pres. Zia said that the USSR wanted to withdraw its more than 100,000 troops from Afghanistan:

* self-determination and three at their word million Afghan refugees now annou in Pakistan should be allowed announce a timetable for to go home "with honour and withdrawal other things will take place." he said.

President Zia repeated his demands that before a settlemeni could be reached Moscow had to withdraw its troops unilaterally, Afghans musi be given the righi of
$5 / 11$ - PT - On his return from visits to Burma \& South Korea, Zia said that there was no "scope" of any direct talks between Pakistan \& Kabul on the Afghan issue. "The protaganists of direct talks were too few to be of any consequence." - Air Marshall Ashgar Khan, leader of Pakistan's Tehrik-i-Istiqlal, stressed the need for direct talks with the Karmal regime in a speech to his party.

- The FRG \& the German Red Cross have jointly established a center for Afghan refugees in Bonn. It will collect food, clothing \& medicine for the 10,000 refugees in West Germany \& help them integrate into the total environment.

- SCMP - An Afghan woman \& her 3 children staged a hunger strike at Tokyo's Narita airport. Their hopes of emigrating to Canada were shattered because their passports were found to be forged.

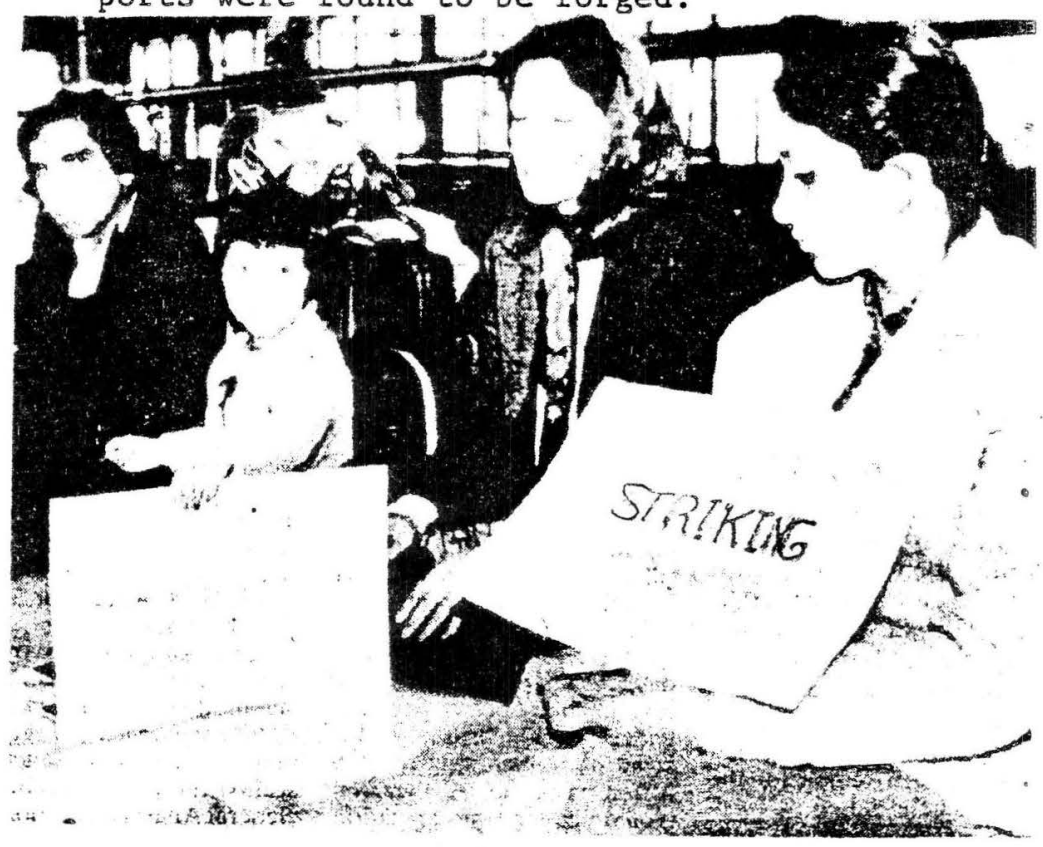

5/12 - PT - Tehran Radio reports that mujahideen have destroyed a military post in Ghor Province.

5/15 - CSM - Soviet commandos killed up to 1,000 people in looting \& burning rampages in the Qarghai district of Laghman in March (See 5/1).

- SCMP - Reports: In Kabul a Soviet tank rammed a bus killing 30-70; guerrilla rockets landed on Soviet soldiers watching a movie in Jalalabad killing 8 \& wounding 17; guerrillas suffered a set back when a leading commander from the Kandahar area defected to the DRA with 100 men (see 
Kabul chron. 4/23, 6/4). The defector has been appointed hea:d of a DRA militia force; guerrillas who threatened to punish the Loya Jirgah delegates have killed 8 so far.

5/15 - NYT - The foreign aid bill:

- As the: Senate worked its way. through the bill, it also accepted on a voice vote an amendment by Sènator Gordon Humphrey, Republican of New Hampshire, providing \$15 million in humanitarian aid to Afghans. Senator Humphrey said the aid was intended to reduce the flow of refugees out of Afghanistan into Pakistan, but it, was not clear how the aid was to reach Afghans. The Administration last week said it planned to request \$4 million in such direct humanitarian aid for the remainder of this fiscal year and $\$ 5$ mil-: lion for fiscal 1986.

5/16 - PT - A police defector says that Soviet advisers are running the Afghan police force.

$5 / 17$ - AICMB \# 50 - Seven leaders of the Afghan resistance formed a new alliance, "The Islamic Unity of Afghan Mujahideen.:(Sسmp. 4)

5/20 - Manchester (CT) Herald - Jack Anderson says:

- Saudl Arabia is trying to set up an Afghani government-in-exile. according to intelligence sources, The trouble with the Saudi plan is that they want ex-King Zahir Shah to head the exile regime.

The king, who was booted out in 1973 and lives in Rome, is not popular with the Afghan rebel who are fighting Soviet invader and their puppet government forces. The Saudis are offering a powerful inducement - $\$ 40$ million in aid to the resistance groups but are unlikely to win any of therb over to the king. The rebels figure, probably correctly, that the Saudis will come up with at least some of the money anyway.

- PT - The PT cites the British weekly "the Mail on Sunday" as stating that thousands of fresh Soviet troops have been airlifted to Kabul recently \& that 20,000 Soviet troops were raiding border villages to demoralize the villagers backing the mujahideen. The paper said that the reinforcements were in addition to the 115,000 Soviet troops already in Afghanistan.

5/21 - NYT - Indian leader Rajiv Gandhi goes to Moscow: ... Indian officials note that Pakistan has fewer troops on its border with Afghanistan than on its border with India. .
6.* To the annoyance of American diplomats, Prime Minister Gandhi has kept up the practice of his mother, Indira Gandhi, of vehemently criticizing the American aid to Pakistan.

He has gone even further, denouncing American covert assistance to the rebels in Afghanistan as creating instability in the region. Aides to the Prime Minister argue that helping the Afghan insurgents only stiffens the resolve of the Russians and even raises the threat of their retaliation against Pakistan.

"If the Government of Pakistan falls as a result, who knows what mess will be left in our lap?" a senior Indian official said.

American diplomats acknowledge that they have been frustrated and sometimes even infuriated by the Indian refusal to denounce the Soviet sweep into Afghanistan in the last week of 1979 , as almost all members of the United Nations did.

But few think. India is likely to change its view, no matter how much it purchases weapons for the West or eases up on socialism at home.

There are those, in fact, who see Mr. Gandhi's trip to Moscow as an attempt to assure Mr. Gorbachev that India intends to stand by its longtime friend despite news reports of Mr. Gandhi's supposedly pro-Western orientation. . .
$5 / 21$ - CSM - Diego Cordovez will go to Afghanistan \& Pakistan to ascertain if it is worth convening 4 th round of Geneva talks on Afghanistan.

$5 / 23$ - NYT - In the USSir Rajiv Gandhi said that the Chinese demand for a Soviet withdrawal from Afghanistan remained a barrier to improved India-China relations. He also said that Gorbachev gave him a "good account of Soviet assertions that Pakistan was backing the Afghan rebels."

- CSM - "Gandhi, like his mother before him. did not directly criti-

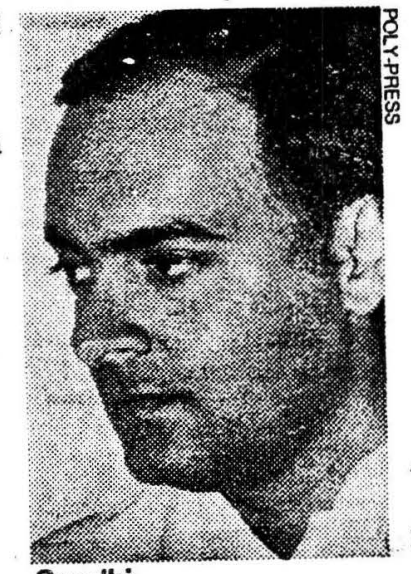

Gandhi' cize the Soviet occupation of Afghanistan. He said Afghanistan did come up during his meeting with Gorbachev \& he conveyed his country's views. 'Our position,' he said 'is very clear. We are not for any country interfering in the affairs of another country.?"

$5 / 27$ - Los Angeles Times - Rone Tempest writes that there are at least 37 organized rebel groups fighting the Babrak regime. The Ittihedi Islami Afghan Mujahideen, the aliance formed earlier this month, is made up of the 7 largest \& most active groups who hope to choose a single 
spokesman from among the 7 leaders to represent the resistance at int ${ }^{8} 1$ forums.

- PT - Diego Cordovez met with the Pakistani Poreign minister to discuss the future talks on Afghanistan. He also met with Pres. Zia \& P.M. Moh'd Khan Junejo.

$5 / 29$ - CSM \& NY Tribune - The Soviets have sent hundreds of tanks \& military vehicles to break the 11-month siege of the army garrison at Barikot in the Kunar Valley. The Jalalabad airport was closed to civil aviation between 5/14-16 as men \& material were airlifted from Kabul. Casualties are beginning to come to the refugee hospitals in Peshawar. - NvYT - The US \& the USSR will meet in late June to discuss Afghanistan.

5/30 - PT - The Mujahideen alliance that was-formed in Peshawar on 5/16 has established a Joint Military Advisory Council that will formulate a strategy against the Soviets. Gen. Rahim Wardak is the group's, spokesman.

- NY Tribune -

ISLAMABAD, May 29 (Reuters) - An offensive by about 10,000 Soviet troops in the Kunar Valley in eastern Afghanistan appears aimed at establisting a large communist base about half a mile from the Pakistani border, Western diplomats said today.

The offensive, Moscow's largest since it overran much of the rebelheld Panjsher Valley north of Kabul last year, aims first at breaking a 10-month guerrilla siege of the border town of Barikot at the valley's northern end, they said.

If it reaches the embattled Afghan army garrison there, they said, the Soviet army would probably station up to 3,000 troops in Barikot to help to seal off rebel infiliration routes along a 60 -mile stretch of the Pakistani border.

"This is a much more forward policy than the Russians have used "before, one military analyst said.

"After the relative success of the Panjsher offensive last year, Moscow has now turned its attention to the borders to stop the flow of men and weapons into the country," another said.

A Soviet base at Barikot, now manned by about 300 Afghan army soldiers and a few dozen Soviet - advisers, would be Moscow's larg. est and closest base to Pakistan. .

$6 / 2$ - NYT - The Soviets are winning in the Kunar Valley \& a 2nd Soviet force is reportedly assembling in the southwest for a drive through Kunar Province.

$6 / 3$ - NYT - Soviet armored forces have seized half the Kunar Valley \& are about 16 miles from Barikot. Over 10,000 Soviet soldiers, including paratroopers, are involved in the assault.

$6 / 5$ - PT - The UNDP refused to entertain Afghanistan's request for funding for a 6-year development program. The UNDP will continue to consider Afghan requests but on a project-byoproject basis. - NY Tribune - The Pakistan Foreign Ministry said yesterday that Soviet \& Afghan planes had violated Pakistan's air space 615 times since 12/79. Last Friday 8 MiG 23s killed 13 \& injured 32 people in 4 bomb \& rocket attacks over Swir in Chitral. The US State Dept. condemned the action. Reporters were flown into Swir to see the devastation. On some occasions Pakistani aircraft have tried to intercept the Afghan planes but so far they have been unsuccessful.

Pakistan has 9 interceptor squadrons with KSec F. . i \}

The poorly-trained Ā army has tried in vain for months to push up the valley to Barikot, where the garrison can now only be resupplied by helicopters vulnerable to rebel heavy machine guns perched on the steep hills nearby...

Apparently deciding to do the job itself, the Soviet army airlifted thousands of men and material to Jalalabad, near the southern end of

the Kunar valley, and began heavy daily bombing raids on May 11 .

A column of over 600 Soviet tanks and armored vehicles reached Asmar on May 21 but was turned back after advancing only three more miles up the unpaved road to Barikot.

The road, which the communists probably want to pave to make it more difficult for rebels to mine, has been cut since soon after the Soviet military intervention in Afghanistan in December 1979...

Barikot is so tightly ringed by mountains that communist jets have occasionally hit their own forces' positions by mistake while trying to bomb rebel bases, the guerrillas said.

According to several recent defectors from the Barikot garrison, one stray raid on May 9 killed 17 officers, dozens of soldiers and seven civilians.
170 Chinese F-6 jet fighters \& 25 -of the $40 \mathrm{~F}-16$ bombers it is buying from the US.

- NYT - Rajiv Gandhi said in

De $\overline{1 h i}$ : the Pakistan-Afghanistan border area was "becoming much too tense" because of the fighting growing out of the Soviet Union's attempt to cut off the supply lines of the Afghan guerrillas.

But he said that "both sides": were contributing to the tension and that he would raise the matter in the United States. He offered no suggestions for resolving the Afghan conflict.

- UN Release - Diego Cordovez discussed his visit to Pakistan \& Afghanistan. He stated that all parties agreed that no military solution was possible but that there was a basis for constructive proximity talks. If progress is made in the June talks, then more talks can take place in July or August - or at least one more time. A settlement has become urgent as the situation is becoming more complex \& difficult. There is a strong desire in Afghanistan \& Pakistan to reach a settlement. 
$6 / 6$ - NYT - A bomb exploded at an Afghan guerrilla headquarters in Peshawar yesterday killing 1 \& wounding 7 .

- PT - Reports: The Jauzjan police chief was killed in a mine blast; 8,000 SovietDRA troops are fighting in Kunar; 2 MiGs were damaged in another guerrilla attack on Shindand airport; the Herat airport was burned 10 days ago.

- NYT - Citizens for America, led by Lewis Lehrman, a wealthy businessman (see Kabul chron. 5/12), sponsored a conference in Angola for representatives of anti-Soviet insurgent movements. The representatives from Afghanistan, Angola, Laos \& Nicaragua formed an alliance - Democratic Int'1. Col. . Ghulam Wardak signed for Afghanistan. tore ne and other participants arrived here on chartered aircraft from Johannesburg.

"Around the world," the letter said, "we see people joining together to get control of their own affairs and to free their nations from outside domination and an alien ideology. It is a global trena and one of the most hopeful of our times."

The participanis, in their declaration, said, "Our cummon goals of liberty and constitutional democracy lead us to form this Demucratic Internation-

al" ".tizens for America, with supporters in more than 300 Congressional districts, has been lobbying on the Nicaraguan rebels' behalf. Mr. Calero said in a conversation that he believed the new alliance would help him argue that if the United States is prepared to support insurgents such as the Afghan Mujahedeen, it should then also support members of the new alliance.

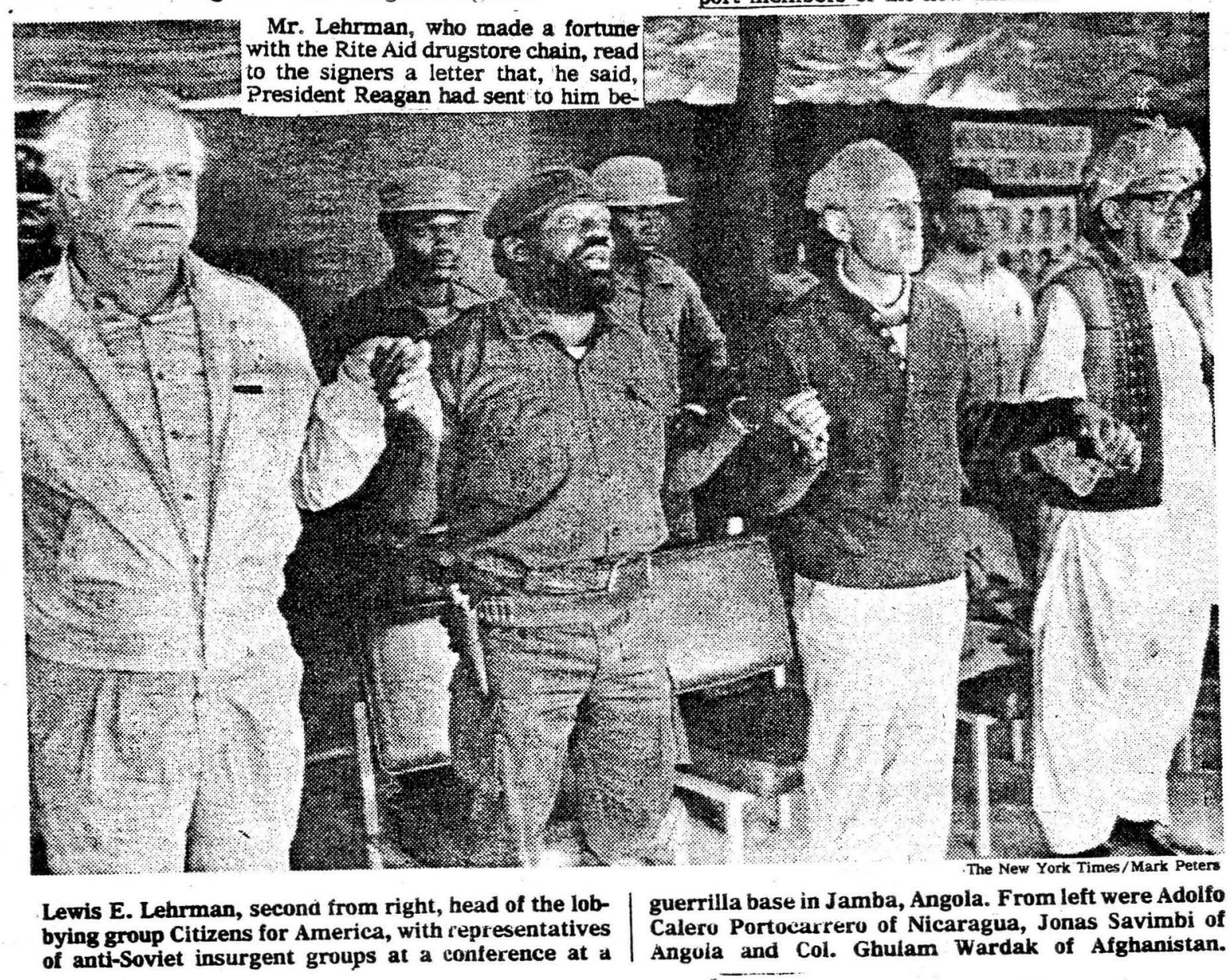

6/7 - NYT - Deane Hinton, the US Ambassador to Pakistan, said in Islamabad that the "US stood fully behind Pakistan in the face of growing attacks \& incursions by Afghan forces \& would maintain its support if the situation deteriorated."

6/8 - Bangkok Post - The Soviet invading force in the Kunar Valley has now reached Narai village where the guerrillas had earlier driven out a commando force in the early, stages of the Kunar offensive. 
$6 / 9$ - NYT - Soviet tanks reached Barikot last Friday night.

$6 / 10$ - Press release - The Senate unanimously passed Senator Humphrey's (R$\mathrm{NH})$ amendment to establish Radio Free Afghanistan. The bill provides $\$ 450,000$ in start-up funds for $1986 \& \$ 250.000$ for 1987. Radio Free Afghanistan will broadcast for 30 minutes every day in Dari \& Bashto. It will be administered by the Board of Int 1 Broadcasting which also oversees Radio Free Europe \& Radio Liberty.

\section{$6 / 13$ - NYT - Rajiv Gandhi in Washing-}

ton: The indian leader has been critical of the $\$ 3.2$ billion in military and economic aid that the Reagan Administra. tion agreed in 1981 to provide Pakistan over six years.

United States officials told Mr. Gandhi that the weaponry was, essentially, designed to strengthen Pakdstan's western frantier, facing. Alghanistan. Mr. Gandhi; attet his lunchwo at the State Department, was asked if he was convinced that the arms were for defensive use on the Atghanistan border.

"We are not fully convinced of that," he said. "We did point out to the President that we would find it difficult to believe that all the equipment that is being used on the Afghan border, especially as some of it is, well, naval seaskimming missiles and other equipment which is not suitable for hill areas."

- In Mr. Gandhi's visit today with Mr. Reagan is well as at a luncheon in his bonior at the State Department, two of the ke points of disagreement between the two nations were discussed. United States officials have been especially States officials have been especia' to unhappy over the refusal of India to
criticize the Soviet Union's combat role in Afghanistan.

Tr. Gandhi said later: "We have discussed Afghanistan and our position on Afghanistan has been very clear that we are not for any country interfering we are not for any counts of any other in the internal arfairs it is happening, it should stop." ...

6/14 - NYT - Rajiv Gandhi before Con-

gress: "We stand for a political settlement in Afghanistan that insures sovereignty, integrity, independence and nonaligned status, and enables the refugees to return to their homes in safety and honor.

"Such a settlement can only come through dialogue and a realistic consensus among the parties directly concerned. The U.N. Secretary General has taken an initiative in this direction. We fully support that initiative."

The allusion was to United Nations sponsored talks involving Afghanistan and Pakistan.

A State Department official said of Mr. Gandhi's remarks: "What is re markable is that he brought it up be tore the U.S. Congress in this way, in terms of the clear desire for a Soviet withdrawal and the re-establishment of an independent nonaligned Afghani stan. He has never said this publicly." "

Mr. Gandhi aftirmed India's long. time position on Afghanistan, saying that "there is a justification" for the presence of Soviet troops since they were "invited by the Karmal regime," a reference to the Soviet-installed Gov ernmert of President Babrak Karmal. Union's entry into Afghanistan was "not very different trom the way the United-States was invited into Gre nada" and that the Soviet and Amer. ican actions in both cases were "comparable" except for the fact that "the U.S has gone back" from Grenada.

In his speech to Congress today, Mr. Gandhi voiced what appeared to be indirect criticism of the United States, including "deep reservations about the militarization of outer space."

- He also criticized, in a pauted way. United States support for the Afghan rebels. He said India was "opposed to both foreign presences and pressures."

${ }^{\circ}$ The one is advanced as a justifica tion of the other ${ }^{\text {" }}$ he added, an an ap. "parent allusion to the Soviet presence -in Afghanistan and the American aid to ,the Pakistan-based Afghan rebels.

6/17 - Press Release - Zbigniew Brzezinski, Ben Wattenberg (Vice Chmn of the Int'l Board of Broadcasting), Louis Dupree \& Ralph Magnus testified at the 4 th hearing of the Congressional Task Force on Afghanistan.

- NYT - Over 140 people were killed when a guerrilla-planted bomb exploded in the Haji Saleem Shah building in Mazar-i-Sharif on $6 / 5$.

$6 / 19$ - NYT - The US \& the USSR opened talks in Washington on Afghanistan. Richard Murphey, Jr., Ass't. Sec'y of State for Near East \& South Asian Affairs, represented the US \& Oleg Sokolov, 2nd in command at the Soviet Embassy in Washington, \& Yuli Alekseyev, chief of the Foreign Ministry's Middle East Section, headed the Soviet side. The US hopes "to provide momentum to UN-sponsored discussions... which resume in Geneva next week." The last Soviet-US talks on Afghanistan were held in Moscow in 1982.

6/20 - NY Tribune - Ismail Khan, Jamiat -i-Islami commander in western Afghanistan, said his men had destroyed the Shahzada Army Post in central Herat city.

\section{$6 / 21$ - NYT - The 4th round of Geneva talks}

began yesterday:

An Under Secretary General of the United Nations, Diego Cordovez, shuttled between the six-member Afghan delegation, led by Foreign Minister Shah Mohammad Dost, and the eightmember Pakistani delegation, headed by, Foreign Minister Shabzada Yaqub Khan, as the teams met in separate rooms at United Nations headquarters here. .

"We have prepared the ground well for this meeting," Mr. Cordovez said "We are starting this discussion with specific documents, specific instruments - documents that contain the I settlement."

- NY Tribune - A State Dept. official on the US -

USSR talks: "The talks were frank and businesslike,"
The talks in Geneva began as American and Soviet officials in Washington completed two days of talks on Afghanistan. Those talks, which ended Wednesday night, were the first between the two Governments on the subject in three years. Mr. Cordovez said he hoped the Geneva discussions could "dispel a little bit of this tremendous distrust there is among the superpowers on a number of issues, and this issue in particular."

"I have the feeling that there is a growing conviction - and this is again not just words - that a military solution is not possible," he told reporters.

\footnotetext{
USSR talks: "Certainly they were not negotiations."
} 
FWURR : HISTIRS DAPLACES

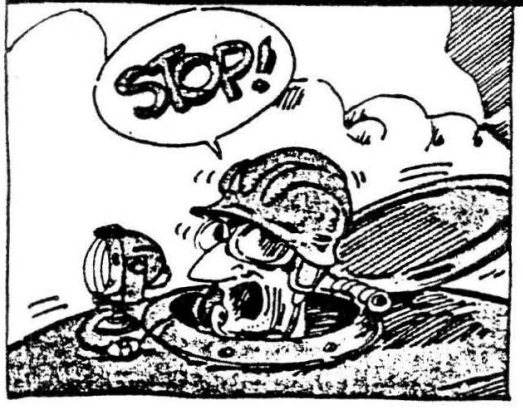

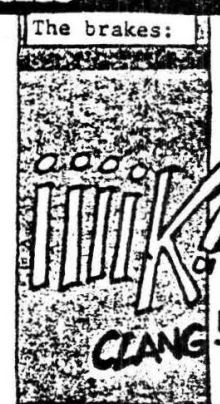

(A Suivre) 89,

$6 / 85$

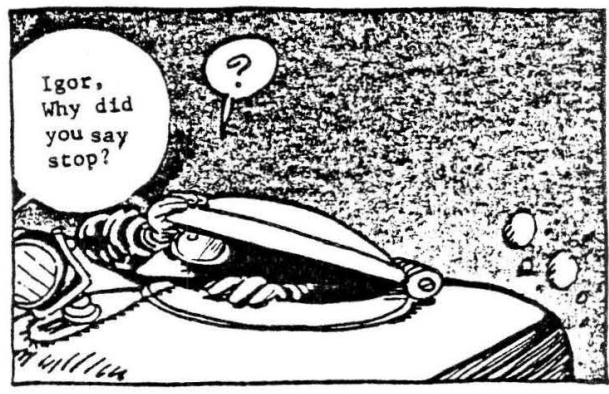

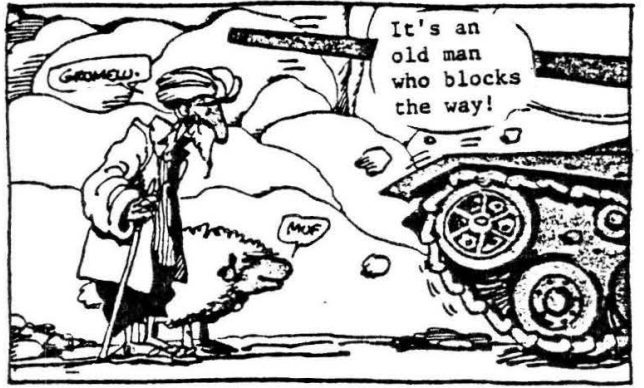

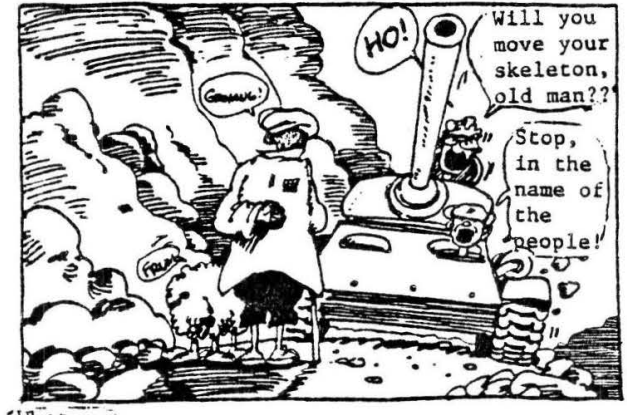

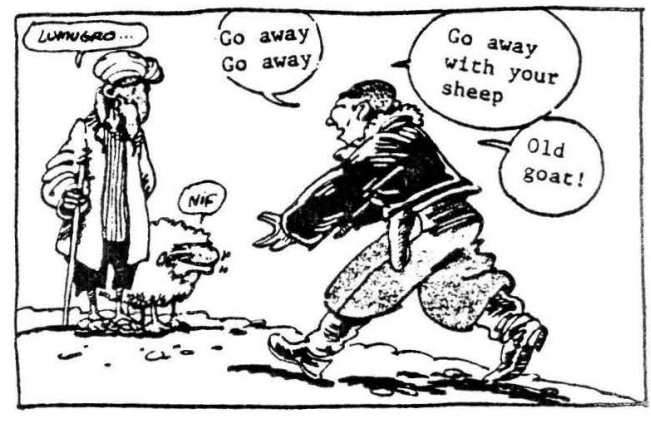

French cartoonist F'Murr leans toward ovine humor $\&$ finds Afghanistan 'graphically interesting.

(translated by

Olivier Roi)
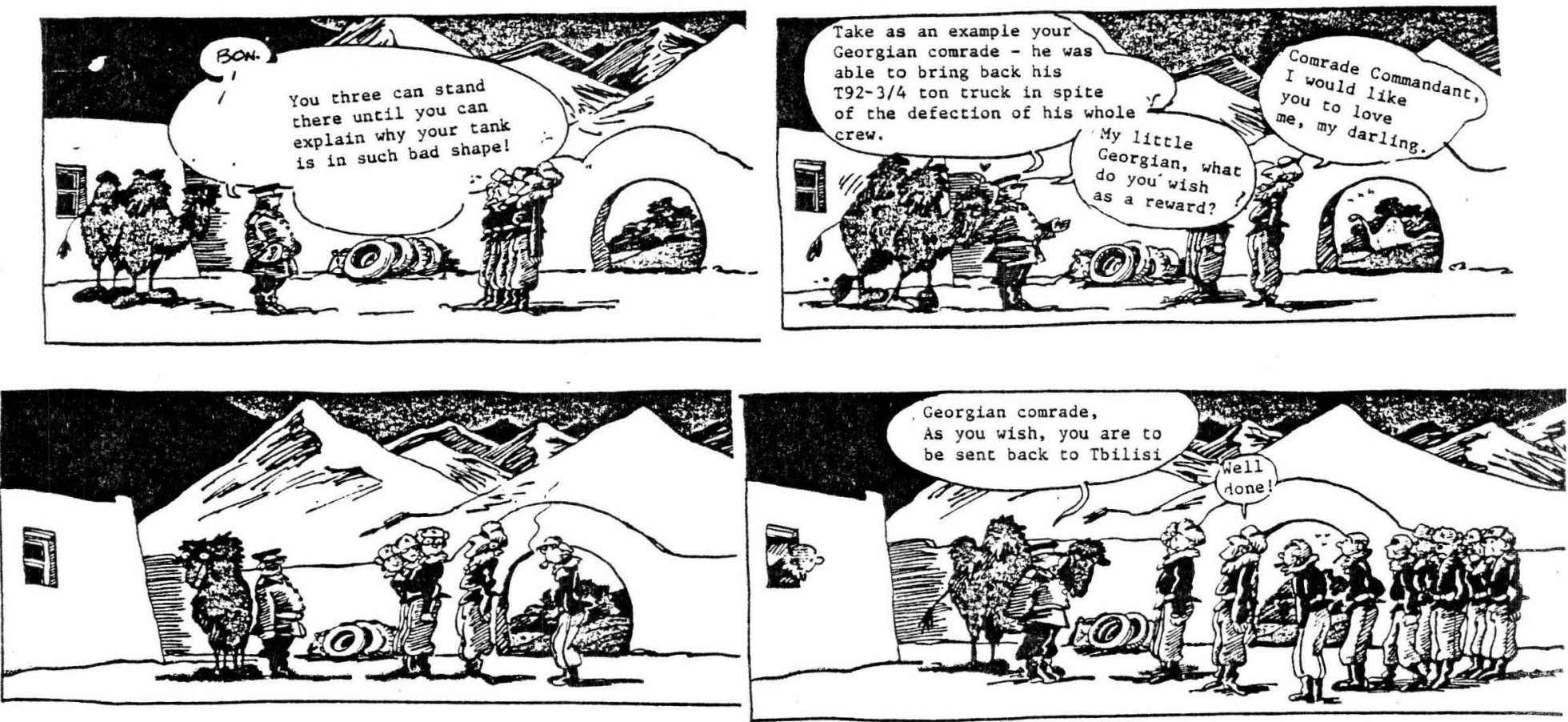
VIEWS OF THE NEWS - One by Paul Wedel of UPI in the Hong Kong Standard of 5/12, another by William Claiborne in the IHT of 5/18-19, \& a 3rd by Christina Dameyer in the CSM of $4 / 29$.

TRUTH has long been the first casualty of war, but superpower interests, inaccessibility and the con. fusion of a guerilla war have made the conflict in Afghanistan particularly difficult to depict accurately.

Reporters are left to sift a weiter of biased sources that include the government-controlled media of Afghanistan, the accounts of rebel leaders and regular briefings by "western diplomatic sources."

The Afghan government, installed by the 1979 Soviet invasion, must take most of the blame because it has generally prevented independent reporters from entering the country.

Requests for visas from journalists covering the war are routinely ignored.

"Because the United States has diplomatic relations with Afghanistan, I feit I should try to get official permission to go," said Los Angeles Times correspondent Rone Tempest.

"But I applied more than eight months ago, I have followed up twice and I am still waiting.

Many reporters have simply slipped across the border from Pakistan.

Last yeas French television reporter Jacques Abouchar was captured by Soviet troops and sentenced to 18 years in prison for trying to see the war for himself

Pressure from the French government led to his release after 40 days in prison, but journalists were warned "next time it will be much more painful."

A cross border trip involves not only risk, but a great deal of time. Most trips take weeks of waiking and dodging Soviet patrois and helicopters for only a fragmentary look at the war.

With the war settling into a routine nearly six years after the Soviet invasion and with major news events occurring in nearby India, Pakistan and Sri Lanka, few publications are willing to invest too much of their correspondents' time in such trips.

Afghan government-controlled media, including Radio Kabul monitored by reporters outside Afghanistan, carries vague reports of "bandits" surrendering or being "liquidated."
Great attention is paid to Soviet economic aid, but there is little Soviet troops in the country.

The rebels themselves issue reports from headquarters in Peshawar, Pakistan, but rivalries among rebel groups competing for outside aid tend to produce inflated claims.

"We Afghans have a flare for exaggeration," admitted moderate Afghan spokesman Mohammad Maiwand. "I am afraid it is in our blood."

And information relayed by Western diplomats may not be much better.

The Afghan government has tightened controls on Western embassies in Kabul even though it wants them to stay in the capital as a sign of the government's legitimacy.

Diplomats are issued a map with a red line drawn around the capital marking the limits of their freedon of movement - recently tightene to only $12 \mathrm{~km}$ from the city centre.

$A$ nightly curfew and $K G B$ surveillance make gathering reliable information even more difficult

Nevertheless, every Tuesday select groups of reporters troop into special "Afghan briefings" held in New Delhi and Islamabad by two Western embassies.

The reporters are allowed into the briefings on the condition they do not 'name the embassies or officials involved in the briefings. No reporters for local publications are admitted.

An embassy official reads a long telex that quotes "multiple sources" and "reliable reports" describing rebel attacks and Soviet atrocities.

"What you get is a ghastly hodge podge of bazaar rumours," admitted one of the diplomats who helps gather the information for the weekly briefings.

Officials for the other embassy refused to explain how their information was gathered or to evaluate its accuracy.

The diplomat said getting any information at all "is very difficult indeed."

The Pushto-speaking diplomat said he spends much of his time walking about Kabul talking to people with information to offer.

Major offensives mentioned in one briefing are often never referred to again. Last year more than 35,000 new Soviet troops were reported moving into the country, but the estimate of Soviet troop strength - 105,000 - was never increased.

There are many reports of atrocities by ill-disciplined Soviet soldiers, but few by the even less disciplined guerillas.

Often reports of events lack essential details such as the date or location. Frequently there is a sub-

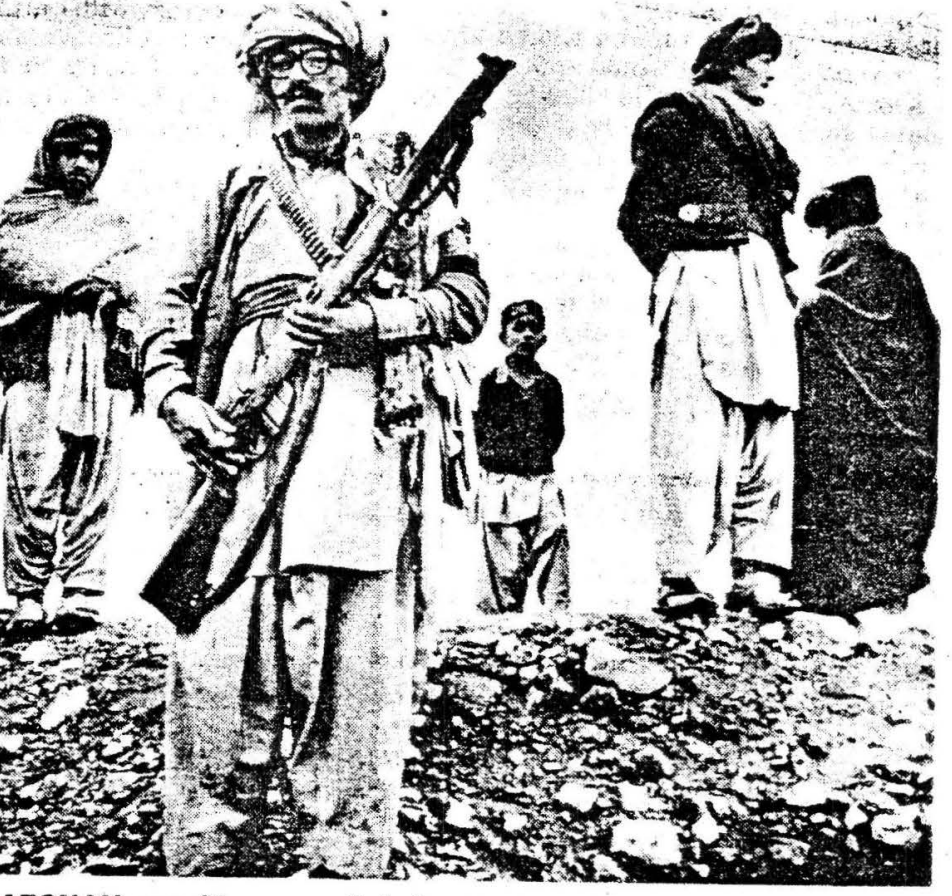

AFGHAN guerillas ... a flair for exaggeration

stantial delay betore even major clashes are reported. French journalise Patrice Claude of Le Monde dubbed the briefings "/es sottises de Mard $i^{\circ}$ - the Tuesday follies.

Claude said he gave up attending them after a trip into Afghanistan with rebeis.

"I went to the first briefing after I came back and they described heavy fighting near Ghazni," he said.

By chance I had been exactly in that area at that time and I saw nothing more than some Kelicopter bombing that hit no one," he said.

Rebel spokesman Maiwand said the diplomats' reports are usually quite accurate about events in Kabul, "but the accuracy drops of with the distance from the capital."

Most reporters acknowledge the problems with the Western diplomatic reports and try to indicate in their stories that the intormation could not be checked.

"Because the information is essentially unconfirmable, we must be very careful and very sceptical," said German correspondent Christian Furst of the German News Agency, DPA.

"But any information is still better than none," he said, "and to report nothing is precisely the desire of those who shut us off from the war - the ones who started it."

\section{By William Claiborne Washington Post Servic}

NEW DELHI - At noon almost every Tuesday, a half dozen or more foreign correspondents based in Islamabad, Pakistan's capital, gather in a windowless room on the ground floor of a Western embassy building for a briefing on the progress of the war in Afghanistan.

An embassy spokesman, who has not been to Atghanistan and who frequently-ștumbles over the pronunciation of the names of unfamiliar towns, begins reading from a long, teletyped cable from his country's mission in Kabul

The spokesman does not have to spell out the ground rules for the briefing, which are well known to the reporters: They can take notes on the reading of the report, but they cannot not use tape recorders or be given copies of the document.

Attribution is strictly limited to "Western diplomatic sources," even though the Soviet Union and the Afghan government are well aware of the briefing sessions and can see through the thinly disguised sourcing that appears in the following day's newspapers. The diplomatic sources readily concede that there is little doubt that their cables have been intercepted by Soviet intelligence.

At the same time on Tuesday, foreign journalists in New Deihi gather around a conference table in the chancery of a Western embassy and listen to a reading of an identical report on the war. As in Islamabad, substantive questions are not entertained, because the briefing officer has no information beyond what is contained in the report.

Usually, the New Delhi-based reporters then go to the nearby chancery of another Western diplomatic mission and listen to the reading of a similar war report, whose details of ten, but not always, mirror those of the other embassy.

In both Islamabad and New Delhi, the correspondents who attend the briefings are, in a sense, a captive audience. They are denied an opportunity to verify the reports, 
does not permit Western reporters to visit the battle zones.

Periodically, journalists slip across the porous Pakistan-Afghanistan frontier with bands of insurgents. But because of the constraints on travel posed by the rugged terrain and the danger from Soviet and Afghan troops, their perspective often is limited to a relatively narrow geographical area.

As a result, in the battle for public opinion being waged by the Soviet Union and the West in the United Nations and elsewhere, the Tuesday briefings by "Western diplomatic sources" has assumed increasing importance.

The most recent offensive in the public relations war has centered around reported atrocities by Soviet troops against Afghan civilians.

These included delayed reports on Tuesday of massacres of about 1,000 men, women and children by Soviet soldiers in Laghman Province in northeastern Afghanistan. The reports said that from March 11 to 18, Soviet Army units burned and looted a dozen villages in reprisal raids against civilians supporting Islamic guerrillas.

Most reporters based in southern Asia who try to monitor the progress of the war do not dispute the view that something sinister, and probably akin to the disturbing diplomatic reports, has been going on in eastern Afghanistan.

For weeks, Afghan travelers who arrive in New Delhi have spoken vaguely of Soviet massacres of civilians in reprisal for assisting the Mujahidin, the Moslem rebels who have been fighting against Soviet and Afghan government troops since the Soviet Union intervened in December 1979.

The Afghan Information Center, which is headquartered in Peshawar on the Pakistani border, and which is regularly in contact with journalists based in Islamabad and New Delhi, has spoken of civilian massacres, although its details often are at variance with those offered in the briefings.

However, it is the numbers of casualties reported that journalists often view with suspicion.

In November 1982, Western diplomatic sources in New Delhi reported a major disaster in the Salang Pass tunnel through the Hindu Kush mountains in northern Afghanistan. Witnesses were quoted as saying that more than 700 Soviet soldiers and 400 Afghan civilians had died in an explosion, and that as many as 2,700 people might have been killed.

The story, emphasizing the death toll, received wide attention in the international press. A month later. the Western diplomatic sources scaled down the casualty total to. 350.

As a result of that and other such experiences, many reporters in southern Asia have become suspicious of the figures supplied in the regular briefings by Western diplomats, particularly those originating in remote areas of Afghanistan

\section{Afghan intellectuals holy war 'by the pen'}

\section{By Christina Dameyer \\ Special to The Christian Science Monitor \\ $4 / 29$}

Peshawar, Pakistan

While the Afghan guerrillas wage their jihad (holy war) against the Soviet occupation forces on the battlefield, a small group of Afghan émigrés across the border in Pakistan is conducting another type of warfare.

"We are doing jihad by the pen," says Prof. Rasul Amin, former dean of social sciences at Kabul University. "The Soviets are conducting a strenuous propaganda campaign to convert Afghan civilians to Sovietstyle communism, and the mujahideen [Afghan resistance fighters] are not equipped to counter it effectively."

Efforts are being made to publicize the Afghan predicament abroad. A group of Afghan exiles has banded together in Peshawar to establish the Writers Union of Free Afghanistan. Members include the former president and several professors of Kabul University and a specialist on Soviet military tactics who trained at the elite Frunze Military Academy in Moscow. ...
Another former Kabul University professor, Yusuf Elmi, plans to start a monthly magazine for Afghans.

Articles appearing in the Western news media will be translated into Farsi and Pashto and distributed in Afghanistan and to refugees in Pakistan. This is likely to raise the morale of guerrillas in Afghanistan by countering Soviet propaganda that the West has deserted the Afghan resistance. But the magazine lacks funding - the general problem with many such projects envisaged by the intellectuals. ...

The educated Afghans - as the group least likely to be deceived by Soviet promises and also able to generate a competing political ideology - were the first target of the Afghan communist regime ufter it came to power in a 1978 coup. By the admission of the succeeding govern-

ment, 12,000 anticommunist intellectuals and professionals were executed. Amin claims that these executions were instigated by agents of the KGB, the Soviet secret police, operating under the guise of diplomats and advisers to the Afghan government.

Dr. Majrooh estimates that 20,000 more Afghans have been killed since the Soviet invasion in December 1979. "We have lost the cream of our society," he says.

Large numbers of the remaining educated Afghans have either been imprisoned or have fled the country. : ?

Many Afghan intellectuals and professionals intended to lend their skills to the Afghan resistance, but most of them have not found the atmosphere in Peshawar conducive to their involvement.

Financial pressures and the lack of facilities for independent work force most refugee intellectuals to take jobs as advisers to one of the resistance parties based in Peshawar. This involves espousing the party's line and style. Many professionals complain that the leadership - in many cases not well educated - is not generally receptive to new ideas.

Discouraged by their inability to play an influential role in the resistance, the vast majority of educated Afghans have started new lives in the West. The result has been a "brain drain" for the resistance.

"I defected because I didn't like the government and thought I had a lot to offer the mujahideen, "says a former Afghan Army colonel. "But it took me months to find a job as a military adviser to one of the parties. I revamped their antiquated training system and military tactics, but my recommendations were all brushed aside because the military chiefs think they know everything already. I'm really sorry I came now. In Kabul, I had a good position and all the luxuries, but here I can barely feed my family on the small salary I get."

Worse some educated Afghans relate that jealous members of their parties denounced them as communist sympathizers to the Pakistani police to get rid of them. Interrogation and sometimes prison followed. Trying to present their view of the situation can even be dangerous. Last year, Azizur Rahman was murdered shortly after the publication of his book, "The Invisible Hand Behind Jihad," which described the shady dealings of the resistance parties.

Afghans living in the United States who went back to help the cause of their country's liberation have also encountered obstacles.

"I wanted to help," said one Afghan, "but there was just no place for me there, so I finally went back to the States" (seep. 20) 
Dut for years, it has been widely known that the United States has joined with Arab countries and others of help provide covert assistance to the Afghan rebels, known as "Mujahedeen," or "koly Warriors," who are waging a fierce insurgency against more than $100 ; 000$ Soviet troops stationed in Alghanistan.

Russian troops began to go into Afghanistan in the last week of 1979 and inštalled Babrak Karmal as leader of the Marxist Government in Kabul.

The Soviet intervention spurred President Reagan to provide Pakistan with a $\$ 1.6$ billion military aid package, including 40 F-16 jet fighters. Today, A prerican officials say these planes, mast of which have been delivered, are haying an increasingly important deterrent effect because of the Soviet violations of Pakistani airspace.

\section{"I 'Deterrence Has Worked'}

Those planes are not meant for Pokkistan to go out and find Soviet planes to attack in Afghanistan," an American official said. "They are meant to prevent the Soviets from attacking the heart of Pakistan. That deterrence has worked."

The official also said the United Stătes was preparing to supply new airtomair missiles to Pakistan for the F.I6's, which he said would increase their "deterrent value."

The. F-16's, however, have also become a focus for criticism by General Zijas's opponents in Pakistan, as well as criticism by officials in neighboring India who regard Pakistan as India's principal rival in the region.

In recent weeks, senior Indian officials have cited the rising air attacks as $^{*}$ evidence that Moscow is taking a toûgher stance toward Pakistan.

A senior Pakistani official said that affer meeting in Moscow in March with the new Soviet leader, Mikhail S. Gorbachev, General Zia concluded that the Russians were growing "impatient" with the stalemate in Afghanistan.

\section{* Effort to Intimidate Seen}

This official said Mr. Gorbachev told General Zia that the Soviet Union was highty concerned about Pakistan's suppart for Afghan guerrillas. The official said Soviet incursions into Pakistani aitspace were thus seen as an attempt to "intimidate" Pakistan in what he called "a war of nerves."

Other officials analyze the incursions somewhat differently. They point out that in the last several months, three key Afghan Government posts in the eastern part of the country have been under siege by the rebels.

The Soviet air attacks are therefore also seen as having a principal purpose of trying to cut off supplies from Pakistan for those carrying out the siege. One of the sieges is said to be occurring at Barikot, and the Russians have attacked supply lines near Arandu inside the Pakistani border.

There have long been predictions that Pakistan would come under increasing pressure to alter its policy of supporting the Afghan guerrillas.

Although there is widespread sympathy for the Afghan refugees who have fled to Pakistan, there is aiso concern that they compete with Pakistanis for jobs. Recently, there have also been concerns that the refugees are engag. ing in smuggling, drug manufacturing and other illicit activities.

In addition, some Pakistanis say they believe the Sovier Union could try to exploit Pakistan's ethnic divisions. For example, they said Moscow could act to fan separatist movements in Baluchistan in the southwest, or to encourage the sort of strife that occurred in rioting involving the Pathans, another ethnic minority, in Karachi last month.

\section{The East-West Rivalry}

But the biggest concern cited by crit ics of General Zia is that his support of Afghan guerrillas, and his refusal to recognize the Karmal Government in Kabul, could sweep Pakistan up in a conflict between Moscow and Washing. ton in which Pakistan would ultimately have no control.

So far, there is no evidence that such criticism is embraced by more than a small if highly articulate, group of dissidents who bave long opposed the President's rule.

Indeed, some knowledgeable politicians say that even if 50 to 60 members of the new assembly might question General Zia's policies, it could turn that only a fraction of that number would actually speak out publicly or vote against them when it comes time to do so.

One member of the assembly said the dissidents were determined to make themselves heard, however. "We will have a debate over the foreign policy of this Government even if only 20 people participate." said Anwar Aziz Chaudhry, a member of the newly elected assembly.

\section{Some See Benefit for Zia}

Others sympathetic to General Zia say a debate could end up strengthening his hand by giving the Government a chance to confront its critics, whose comments are appearing more and more frequently in the press lately.

General Zia's aides argue that giving legitimacy to the Soviet presence in Afghanistan could hasten the day when Moscow might feel tempted to extend its control to Pakistan, and that the critics themselves have not been forced to deal with this possibility.

General Zia, at a news conference last week upon returning from a trip to South Korea and Burma, said he was confident that Pakistanis would continue to support the Afghan insurgents.

"I hope the National Assembly will discuss it." he said, "but I know that on this issue there is no possibility of compromise. Our policy towards Afghanistan is practical, and morally correct." 
And so the Government, although not
denying Ambassador Smirnov's asser-

T. BY STEVEN R. WEISMAN

i.) Special to The New York Times

'PESHAWAR, Pakistan, May 12 -

The only visible clue that something

Foùt of the ordinary happened here re-

cently is a pile of rubble and a couple of crumpled mud huts in a dusty "train"ing camp" run by refugees from Afghanistan in a nearby village.

w. It looks like the remnants of an exploS10n, and indeed the only thing on which people agree is that an explosion did occur at the village of Zangali two weeks ago. A dispute over why and how it happened has resulted in reverberations, jitters and embarrassment among senior officials in Pakistan.

i) Both the Soviet Union and the Afghan Government charge that the explosion bccurred when several Russian and AfGhan prisoners held inside Pakistan; ' tried to escape and managed to blow up an ammunition depot at the refugee camp some 15 miles south of here.

$\therefore$ "Soviet and Afghan soldiers fought rogether heroically, and in the final thoment blew up the stockpile and themselves," said the Soviet Ambassador of Pakistan, Vitaly S. Smirnov, who protested the episode in Islamabad.

\section{'Involvement of Pakistan'}

$\because$ "This incident shows the incroasing involvement of Pakistan in an undeclared war against Afghanistan," Mr. "Simirnov said. "It shows the increasing use of Pakistan territory by foreign countries to create a military center where they train Afghan bandits thrown out by the Government."

Here in Pakistan's North-West Frontier Province, only 20 miles from where the Khyber Pass slices into the rugged mountains of Afghanistan, there are secrets and there are secrets.

It is an open secret, for example, that Pakistan, the United States and some Arab countries are providing huge amounts of covert assistance to Afghan guerrillas fighting the Soviet-backed regeime in Kabul.

\section{No Admitting the 'Secrets'}

It is an open secret that the guerrillas are using dozens of camps in Pakistan as a base to supply the five-year-old Afghan insurgency. And it is a semiopen secret - which is to say that many peaple believe it to be true - that some of the bases in Pakistan contain Russian of Afghan prisoners seized by the guertinlas in Afghanistan.

But for anyone to admit any of these "secrets" is to undermine the ability of President Mohammad Zia ul-Haq to deny that Pakistan is helping to make war against its neighbor.

The denials help retain a minimum of civility in the relationship between Islamabad and Kabul, not to mention Moscow. The denials also permit General Zia's Government to protest innocently when Soviet MIG's sweep into Pakistani airspace, or when Soviet or Afghan rockets and mortars come flying across the border to destory guerrilla bases here.

Pakistan officials say the attacks are increasing as part of a Soviet campaign of intimidation. tion about the explosion, has refused to confirm it and probably never will.

The Government's position is all the more precarious because soon the. newly elected National Assembly is likely to take the unusual step of debat. ing the wisdon of Pakistan's involve. ment in the Afghan war.

\section{Embarrassing Questions}

At the least, Government officials say assembly members are likely to raise embarrassing questions about situation on the border. The Government is expected to come under some pressure to revise its original contention that the explosion occurred in clash between two rival groups of "Mujahedeen," or "Holy Warriers," as the guerrillas are called.

Added to the Government's problem is that in this frontier city, where bearded and turbaned Mujahedeen wander about with rifles and where smuggling and drug dealing are common, tall tales are a way of life. The busiest marketpiace in Peshawar is known as the "Story Tellers' Bazaar."

Not surprisingly, interviews with half a dozen people convinced of what happened at Zangali yielded at least half a dozen versions of the story.

\section{Russians Said to Die}

The training camp is down a rutted road in a hilly area not far from a Pakistani Air Force base at Badabir. (The base is famous for its own secrets. From there, Francis Gary Powers took off in a U-2 spy plane that was downed by the Soviet Union in 1960 .)

Outside the camp, Afghan guards refused entry to a reporter and declined to comment on the incident. But a man who identified himself as a recruit at the base said later that he had observed the episode and that 11 Soviet soldiers held prisoner there had died.

One of the prisoners, the man said, had managed to convince his fiercely religious captors that he had converted to Islam, and all the prisoners joined the Mujahedeen in prayers each day.

During evening prayers on April 26, he said, the prisoners killed a sentry and seized control of the camp.

Meanwhile, villagers reported that exchanges of fire went on ail night. "In the morning, there was a big explosion," said a man named Khaistabaz, a 45-year-old school guard. "Some shrapnel hit the village. No one in the village was hurt, thank God."

A spokesman for the Afghan resistance group that runs the camp ac knowledged that some Afghan, not Soviet, prisoners died when a depot containing mortars, rocket-propelled grenades, rockets and ammunition blew up.

But he denied there had been any. re volt by any prisoners, asserting instead that the Soviet Union was distorting the episode to justify its air attacks and

Incident at the Khyber Pass

The Zangali episode resembles an other incident that is said to have ocZangali and the generally volatile bombardments in Pakistan. curred in March at the Torkham border post in the Khyber Pass west of here. reported that at Torkham, three Afghan Army deserters fled into Pakdstan, but that after three days of tank and artillery fire, Pakistani authorities were forced to return them to Afghanistan. Some people here say they think the incident occurred, but many do not. The Torkham post is continually fought over, much to the dismay of Pakistan, which has always wanted to keep it open and neutral so that the lucrative trade with Afghanistan can proceed peacefully.

Pakistan has never been able to prevent Afghan guerrillas from attacking or even capturing the post. Last year, in such an attack, several Afghan civilian border personnel fled for safety into Dakistan, oniy to be asked to be returned when the fighting died down. Pakistan complied.

Government officials say they think this is what again happened in March.

and from the LOS ANGELES TIMES 5/23 SovietsThreaten to Raid Afghan Pakistan Bases

\author{
BY RONE TEMPEST, \\ Times Staff Writer
}

ISLAMABAD, Pakistan-A massive explosion last month in an arms magazine at an Afghan rebel base inside Pakistan has triggered new Soviet warnings to Pakistan suggesting that the Soviet Union may be considering military raids across the border against such bases.

Soviet diplomats say that at least 12 Soviet prisoners of war died in the explosion. A senior Soviet diplomat said in an interview here Tuesday that "the Pakistanis are playing with fire" for allowing the moujahedeen rebels to conduct anti-Soviet operations inside Afghanistan from the bases in Pakistan and to hold Soviet prisoners here.

The diplomat, one level below ambassadorial rank, asked that his name not be used but said his statements could be attributed to the Soviet Embassy. The 90-minute interview took place at the embassy. ...

"We know the concrete locations of each of the moujahedeen bandit training camps," the Soviet diplomat said. "We also have maps to show their locations. (See P. 32) 
"So far," he said, pausing for emphasis, "we have not come across the border in "hot pursuit."

The diplomat, who accompanied the Soviet ambassador here to a May 11 meeting with Pakistani President Zia ul-Haq, said they had warned Zia of the consequences of holding Soviet soldiers prisoner in Pakistani territory: _.

Last July, the estimated 120,000 Soviet troops inside Afghanistan began intensified operations, particularly along the Pakistan border. Pakistan government officials say that Soviet and Afghan aircraft frequently fly over Pakistani territory and bomb some border locations.

In March, at the Moscow funeral of Soviet President Konstantin U. Chernenko, the new Soviet leader,

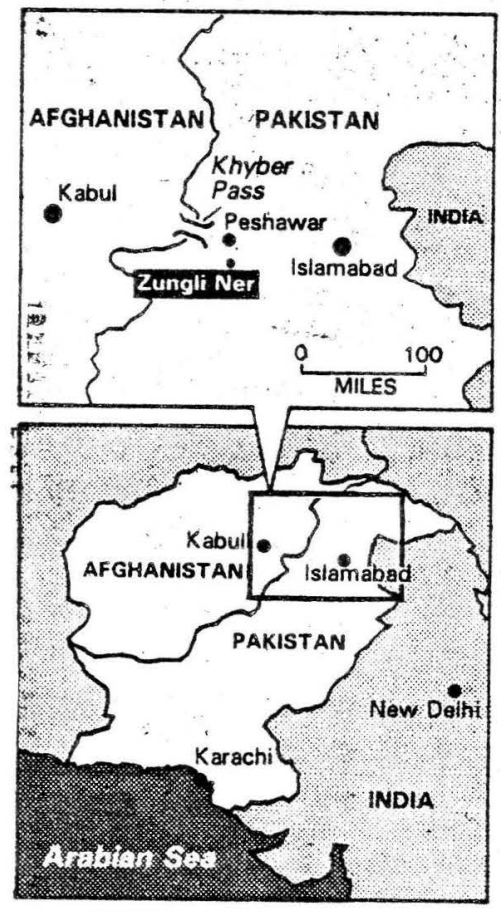

PATRICX LYNCH / Los Angeles Times

Mikhail S. Gorbachev, warned Zia to stop helping the moujahedeen by giving them safe haven inside Pakistan.

Zia later told an Indian journalist: The message was that he (Gorbachev) felt Pakistan was interferIng in the internal affairs of Afghanistan and he said, 'Lay off.' " Publicly, Zia has not expressed sears of Soviet raids into Pakistani territory, and most Western diplomats discount the threats as hyperbole.

"They (such raids) would be tifficult logistically," one of the diplomats said Wednesday. "You swould have to come through in force. You would have to take on a : confrontation and you have to get out. Very unlikely they could do it without taking casualties. It would also be bad public relations. They could not do it without looking like the big guy taking on the little guy."

Soviet anger has been heightened by the explosion April 27 in the village of Zungli Ner near the town of Badaber in Pakistan's North-West Frontier provinee.

Despite Pakistani government denials, most Western diplomats interviewed believe that the blast did result in the deaths of 12 Soviet prisoners and possibly 12 more Afghan army prisoners who were holed up in the arms depot after an escape attempt. . .

According to the Soviet diplomat interviewed here this week, the escaping Soviet servicemen asked to be turned over to the Soviet Embassy in Islamabad or to Pakistani authorities. Instead, he said, Pakistani military officials on the scene participated in their "massacre."

After the explosion, which reportedly could be heard 10 miles away, the Soviets demanded that those responsible for the deaths be punished, that the remains of the Soviet prisoners be handed over to the embassy. here and that all other Soviet servicemen inside Pakistan be turned over to either Pakistani or Soviet officials.

In its response, the Pakistani government denied that any Soviet troops were killed in the explosion, which a government spokesman said was caused by agents provocateurs.

"We have firm proof that there are still other Soviet seryicemen in Pakistan territory," the Soviet diplomat said in the interview. ${ }^{\text {"O Our }}$ numbers differ from 50 to 120 . We know the bandits transfer the prisoners in and out of Afghanistan so you can't be sure how many are on Pakistan land. But they are, and the Pakistan authorities know that we know they are."

At Zungli Ner, early on the morning of April 27, the villagers heard staccato bursts of gunfire at the nearby Afghan rebel base. Then the sky above the small collection of mud-walled dwellings exploded into a fiery rain of rockets and twisted sheets of metal and splintered wood:

"We could not see because of all the burning around us," said Rehan Khan, a village leader in the area, about 50 miles southeast of the Khyber Pass. "We looked up and there were rockets on the right and left of us, all around. We thought we were all finished."
Although reports of the explosion differ slightly, the main account remains basically the same, whether told by a village leader in Zungli Ner or a political leader in Peshawar, where most of the moujahedeen groups are headquar. tered. That account includes these details:

Several months ago, about two dozen prisoners of war were taken to the Zungli camp. The camp, on 20 acres of elevated barren land near a canal that carries water to the area from the Kabul River, has sentry posis at four corners manned by men with Kalashnikov assault rifles.

Village children, allowed to play along the edges of the camp, say they often saw the Soviet soldiers in the camp. Village leaders nearby and Afghan rebel sources said at least two of the Soviet soldiers were of Asian descent, from one of the Muslim-populated Soviet territories that border Afghanistan. The others-there were at least nineappeared to be light-skinned Europeans.

Recently, a large arms ship-' ment-including unusually large supplies of rocket-propelled gre. nades and Chinese-made 107 -millimeter Katyusha rockets - was delivered to the camp. The United States, through a covert program of the ClA, is a major supplier of such weapons to the Afghan guerrillas.

After the explosion, many of these weapons, including unexploded shells, were showered over neighboring villages. Several of the rocket-propelled grenades bearing Chinese markings were shown to a visiting reporter by villagers.

According to several sources, some of the Soviet soldiers managed to persuade their captors, who were members of the Jamiat-i-Islami faction of the moujahedeen, that they had converted to the Islamic faith. The moujahedeen let down their guard and, on the night of April 26, the Soviet soldiers as well as some Afghan prisoners managed to seize weapons and take control of the earth-walled arms magazine in the center of the camp.

Villagers said that on that night, civilians staying in the rebel camp left hurriedly, saying the Soviets had taken over the camp. Sometime that night, the leader of the Jamiat group, Prof. Burhanuddin Rabbani, went to the camp and attempted to negotiate with the Soviet soldiers. Rabbani, they said slept that night in a large guest house in the village. .

At about 8:30 a.m. on April 27, by most accounts, the arms magazine blew up and explosions continued intermittently until noon. 


\section{In campaign to 'Sovietize' Afghanistan, USSR uses school, media, and ethnic ties}

By Christina Dameyer $\quad 3 / 26$

Special to The Christian Science Monitor

Peshawar, Pakistan

Although the Soviet Union's military offensives against Afghan guerrillas and civilians have attracted attention in the West, its campaign of political and cultural "Sovietization" has been much less noticed.

Some analysts say that most of the Soviet effort in Afghanistan is directed at political indoctrination. The Soviets, they say, are trying to make the Afghan people adopt communist and pro-Soviet ideas and subvert the Afghan resistance to ensure the success of this policy.

Over the past seven years the Soviets have tried hard to convert Afghanistan from a neutral buffer state into a Soviet satellite. Educational and political programs are being used to achieve this.

The Soviets consider education to be of crucial importance in helping the people understand Marxist-Leninist concepts. (Afghanistan is 90 percent illiterate.)

"You never see an illiterate communist," one observer says.

Rasul Amin, a former Kabul University professor and a specialist on the Sovietization of Afghanistan, explains that the Soviets managed to build up the Afghan Communist Party in the 1960s and 1970s by attracting partially educated people.

"These people are the most fanatic believers, because they blindly follow the party line without the power of reasoned questioning brought by education," he says.

The educational campaign involves study in the Soviet Union for Afghan students and Soviet-sponsored training programs in Afghanistan. Since the communist coup in 1978 , some 1,500 university scholarships have been given out each year, up from 50 to 100 in previous years. East-bloc countries al locate some 500 scholarships a year to Afghan university students.

Although exiled Af $\mathrm{Af}_{5}$ ans and Westerners often say that the students are forced to go to the Soviet Union, the Afghan government is in fact swamped with applicants. A former Foreign Ministry official estimates that 3,000 to 4,000 Afghans apply annually for the 1,500 places.

Education is free in Kabul; though many young Afghans prefer to go to Soviet universities for three main reasons: to avoid military service; to get higher quality technical and medical training; and to enjoy the higher standard of living in the USSR. A smaller munifier go because they are Afghan Communist Party members and can look forward to good jobs and high salaries upon return.

According to a former Kabul official who dealt with educational exchanges, there are between 15,000 and 20,000 Afghan students - from grade-school to college age - in diverse parts of the Soviet Union, including Siberia. The former official says there are assorted other groups studying there,' from kindergartners to the most elite militiamen, who receive six months to one year of advanced military training in Central Asia. He estimates that 350 Afghan teachers are sent each year to the Soviet Union and East Germany to learn how to teach communist ideas more effectively.

The Soviets have made sure that Afghans at home don't miss out. Aside from increasing political indoctrination in schools and universities, a propaganda campaign is under way to reach the general population, according to Asmat Khan, a researcher at Peshawar University's Central Asian Studies Ceñter.

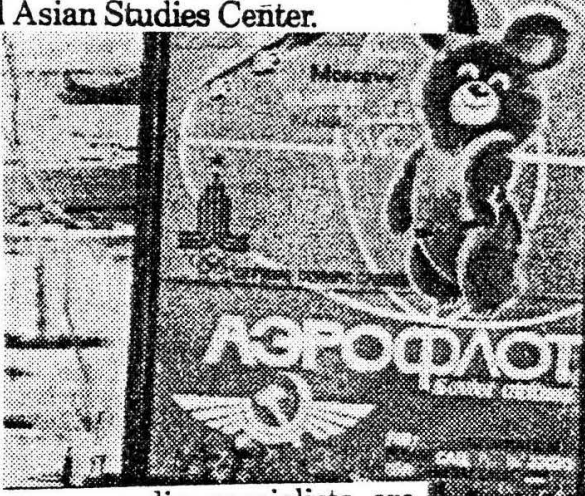
Afghan government ministries. The Soviets have even sent Iranian communist party members (who had fled to the So. viet Union) into Afghanistan posing as Soviet Tajiks, according to Soviet Analyst, a scholarly bulletin published in helping. These lranians are said to be nist Party and build up its membership. The Soviet Analyst speculated that some According to Khan, the goal is to dis solve feelings of Afghan nationalism and encourage ancient animosities. The way will then be cleared for each ethnic group to beought under control of the Kabul regime. This was essentially the same Asian republics in the 1920 s and ' 30 s.

Although the Afghan Communist Party claims 200,000 members, recent Afghan emigrés agree that only about 1,000 rest are "radish communists" - red on the outside, white on the inside.

Soviet-inspired policy has greatly reduced the educational standards of Afghanistan, analysts say. According to Afghan sources, high school has been terminated at 10th grade. Eleventh and

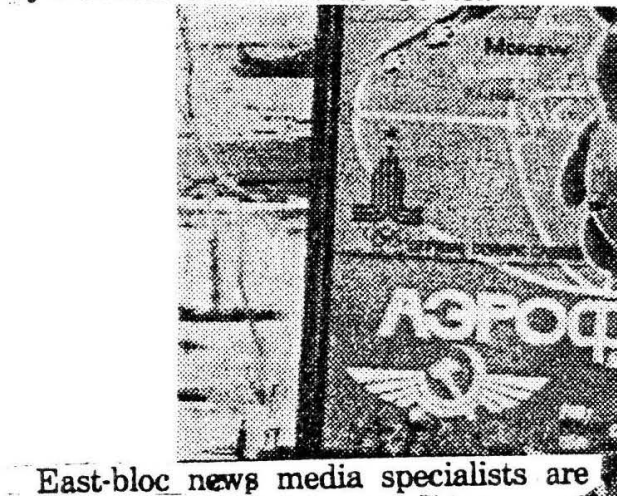
training Afghan journalists in how to present the Soviet system more attractively. And for two years the Soviets have been circulating magazines for party activists, farmers, and workers.

Much propaganda is aimed at building ties between the northern Afghian nationalities and their ethnic cousins in Soviet Central Asia. Uzbek and Tajik radio programs, newspapers; and literature published in the USSR land broadcast or distributed in Afghanistan) try to convince northern Afghans that their historicat links are across the Soviet border, rather than with neighboring Iran and Pakistan. The message is that Soviet Central Asians are better off under communism.

To convince Afghans that goods and services offered by the Soviet system are superior, Mr. Khan says, bartering across the border is encouraged - an Afghan horse for a Soviet refrigerator, for example. Afghan Tajiks can now cross into Soviet Tajikistan for free medical care.

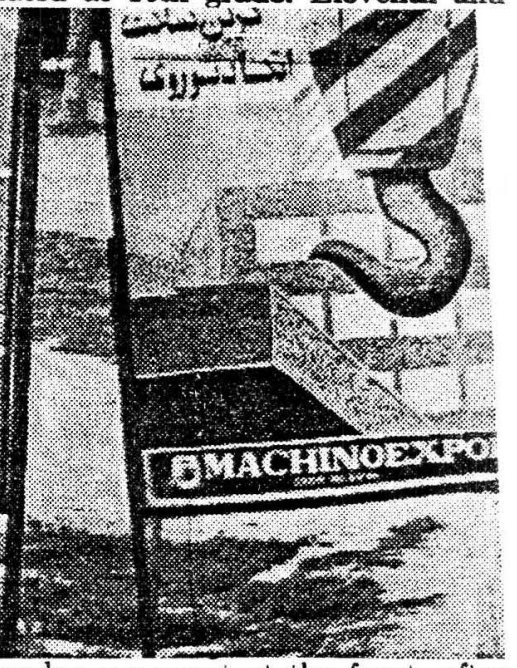

12th grades are spent at the front, after. which the boys are given high-school diplomas. If they stay in the Army for three years, they are admitted to university on a scholarship without an entrance exam.

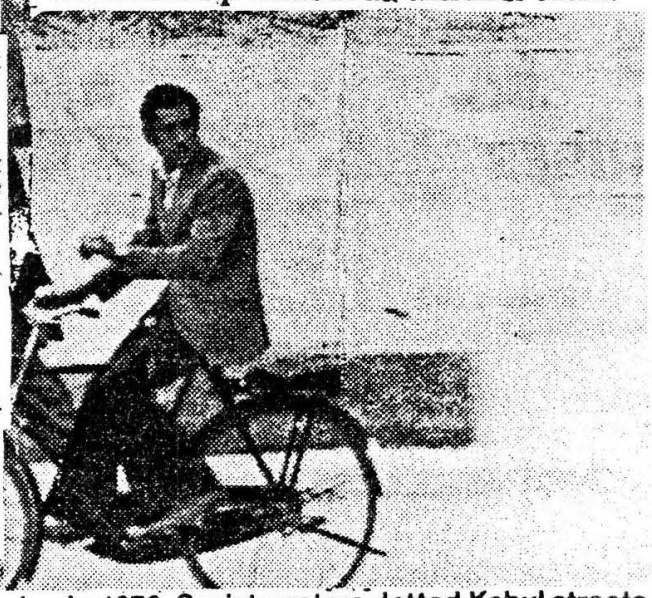


KILLING THE FIELDS: THE OTHER AFGHAN WAR by Sayd Majrooh in the WSJ $6 / 3$.

PESHAWAR, Pakistan - The Soviets are fighting two wars in Afghanistan: a purely military one against the resistance fighers, and an economic one against the rural population.

The military one dominates the head. lines, as last week when Soviet troops began massing in the east to block resistance infiltration from Pakistan. But while the Soviets have largely succeeded in controlling the cities, they haven't been able to control the countryside, home to the majority of the population. In Soviet eyes, the rural communities, in which the resistance fighters move like fish in water, must be destroyed.

After its invasion of December 1979 , the Soviet Union's original tactic was to destroy the villages surrounding the urban areas. This has forced the population to flee to resistance-controlled areas, Soviet-controlled cities or Pakistan. In all three cases, the Soviets believe they are gaining: A growth in the number of refugees outside Afghanistan means increasing social and economic pressure on neighboring countries; an increase in the number of refugees in resistancecontrolled areas brings economic and social problems for the population supporting the resistance; and refugees who take shelter inside the cities come under the Soviets' direct control.

Afghans still living in rural areas are suffering deeply under the massive impact of the Soviet war machine. Because of the fighting, normal exchanges between the countryside and the towns have been disrupted. Roads have been cut and transport is disorganized.

In any event, few farmers have any surplus to sell. In some rural areas, the bazaars have ceased to function. A small rural trader typically is reduced to onequarter of the business he was doing before the Soviet invasion.

The countryside also has been deprived of its labor force. Men between the ages of 18 and 50 have joined the resistance. The women, children and older men who have stayed behind are not producing enough to maintain agricultural production at pre-war levels. Much farming has to be done at night since during the day farmers are targets for Soviet bombers.

Military operations aimed at resistance groups often damage civilians. Whenever a resistance group is spotted, the whole area is heavily bombarded; houses are destroyed and harvests are burned. But the most serious operations are the ones that systematically aim to destroy the agricultural economy. Since 1982 the Soviets have followed the same course of action in Ghazni, Logar, Wardak, Nangrahar, Zabul, Kandahar and Herat:

- Motorized units have raided villager killed cattle, burned foodstocks and da. maged fields.
-During harvest time, the Soviets have set fire to grain reserves.

-Villages and vegetation along the main roads have been completely razed.

- The irrigation system, the main basis of agriculture in Afghanistan, has been badly disrupted. Bombs dropped from the air or explosives thrown inside karezes-underground irrigation canalshave seriously destabilized the system. Some karezes have ceased to give water; others are producing less than half their normal capacity. Furthermore, the ka. rezes need constant care, which they no longer are getting.

The juis, or surface irrigation channels, are facing the same problem. They need to be drained and cleaned, and the dams damaged by the spring torrent of melting snow must be repaired. Apart from the enemy bombardment of the dams, which has occurred in many pla. ces, the absence of male workers means that the juis are filled with mud and water is not flowing. In places such as Kandahar, the Russians have established military posts along the major irrigation channels and kept villagers from their usual work on the water system. Kandahar, which used to be one of the country's most fertile provinces with the best irrigation system, is suffering from a lack of water. Fields and orchards no longer are receiving enough water, and pomegranates and grapes are dying.

Despite the growing difficulties of the rural population inside the country, there are some encouraging trends. Along the routes used by the resistance fighters are small bazaars, where people eat and rest and where small traders and transport. ers are doing business. When one com. mercial center is destroyed, another springs up nearby.

The most encouraging aspect of the situation is that despite the constant threat of air bombardment and ground attacks, farmers are still holding on to their land. The tendency of villagers to leave their homes has been reversed. The refugee camps in Pakistan have lost their attraction, and families prefer to stay at home as long as conditions don't become utterly impossible. They are re building their houses and digging underground sheiters.

If a village is destroyed, the inhabitants of nearby villages don't leave; they continue working their fields. In one district in Ghazni Province about eight out of 10 villages in the main valley were demolished. The surviving villages are empty but the villagers in the side valleys go on collecting their harvests. In Panjsher, the lower half of the valley has been depopulated, but in the upper part agricultural activity is continuing.

All over Afghanistan many villages are surviving in this manner. Afghans remain firmly dedicated to cultivating their land-even under the gun of the enemy. This unarmed civilian population is resisting in its own way against the invasion forces, and in the long run its resistance may be as significant as that of the armed groups.
Comelius Van Hemert Engert, a retired diplomat who was one of the State Department's foremost experts on Middle Eastem affairs, died of pneumonia Sunday at the Washington home of his son. He was 97 years old and had been living in Washington.

His field of expertise led Mr. Engert to many difficult and even dangerous postings. As this country's representative in Ethiopia be watched the African nation fall to Fascist Italy in 1936 and was personally commended by President Franklin D. Roosevelt and the United States Senate for defending bis unprotected legation in Addis Ababa against bands of marauders.

When he was the American Consul General in Beirut in 1941, hard-pressed Vichy French garrisons in Syria and Lebanon were being overrun by British and Free French forces. Mr. Engert became the intermediary in negotiations to avert further bloodshed.

In 1912 , he became this country's first Resident Minister in Afghanistan. Washington had established relations with Kabul in 1926, but it had taken another 10 years before the American Minister to Teheran was also formally acredited to Afghanistan.

\section{Retired in 195}

Mr. Engert remained in the Kabul post until he retired from the Foreign Service in 1945. In recognition of his service he later was given the title of Ambassador.

Aiter his retirement, Mr. Engert continued to travel extensively in the Middle East and elsewhere on special missions for United Nations relief operations, as a representative of the Wurld Bank and as a lecturer.

Mr. Engert was born in Vienna of Dutch parentage and was brought to ine United States as a child. He graduTited f from the University of California and its Law School and studied at Harvard before joining the diplomatic service in 1912 .

Fluent in about a dozen modern languages, Mr. Engert became one of the few ranking Amierican Foreign Service officers of foreign birth and parentage. His first posting was to the Embassy in the Ottoman Empire, first as a student interpreter and later as consul.

A series of assignments followed, including postings to Europe, China and Latin America, but mostly to Middle Eastern countries. While in Teheran in 1922, he became the first American diplomatic officer to pay a visit to Kabul.

Mr. Engert had barely arrived in Addis Ababa, Ethiopia, from Cairo, in 1935 when the sinmering Ethiopian crisis came to a boil. In the ensuing war, Mr. Engert served as a go-between for the Roosevelt Administration and Emperor Haile Selassie:

Mr. Engert is survived by his son, Roderick M. Engert of Washington; a daughter, Sheila Gillen of Geneseo, N.Y.; and six grandchildren.

by Holfgang Saxon in the NYT 5/15 
In 1985, the sixth year of UNHCR's humanitarian programme for Afghan refugees in Pakistan, the Government and $U N H C R$ have, for the first time, signed two agreements to emphasize the shift in trend of the programme from a care and maintenance operation to one geared more towards making the refugees partially self-reliant. The assistance programme in Pakistan had indeed presented a unique challenge.

The first agreement concentrates on basic relief assistance still required for newcomers and newly registered refugees, as well as funding basic services such as health, water supply, and cooking and heating requirements. The second agreement concentrates on services which relate to making the refugees more self-reliant (education, vocational training, income-generating activities on a small scale, assistance to occupational groups, small kitchen gardening projects, poultry farming and beekeeping).

$A$ report on the social integration of Afghan refugees in Pakistan was published recently by the United Nations Research Institute for Social Development (UNRISD). It is summarized below:

The report, written by Hanne Christensen and financed jointly by UNHCR and UNRISD, is the second in a series of surveys on the comparative problems of social adaptation of refugees. The first focused on Afghan refugees in Baluchistan. The present report deals more specifically with the food situation and related socio-economic aspects among Afghan refugees in the North West Frontier Province (NWFP), and their relationship with the surrounding local population.

Hanne Christensen selected four main issues for evaluation: the question of the sources of refugee food and income, the links between refugees and adjacent local population, the extent to which the free provision of food serves as an incentive and or disincentive towards refugee selfsufficiency, and feasible approaches for identifying and assisting vulnerable groups. Ultimately, the objective of the survey was to provide decision-oriented information on refugee needs in relation to their food supply and the uses of relief.

The report first gives a short history of the emergency relief operation. It explains that until the middle of 1982, assistance programmes for Afghan refugees were geared towards emergency relief. But, it points out, "in Pakistan, emergency programmes for refugees have been extended again and again".

There were reasons for this state of affairs. Those refugee workers and field officers who were present during the early part of the operation will remember that the programme of emergency relief was geared towards some 450,000 refugees. Within two years, that number reached over 2 million refugees. To the credit of the people of Pakistan, in the initial stages the Afghan refugees were fed and sheltered by the local residents in extraordinary acts of charity and hospitality.

In its early stage, the UNHCR operation focused on helping to meet "the urgent needs and solving the acute problems of a deprived population. Some three to four years later, a situation has evolved in which refugees are only partially dependent on donated relief'. Consequently, "UNHCR policy was re-oriented from emergency assistance to selfreliance".

\section{Findings}

The report found that distribution of food and other relief items was more regular in government-controlled districts than in areas under tribal control. The refugees in both areas were found to purchase supplementary fresh food with cash income. Poultry-raising was being developed by the refugees in both communities and, in Barawal, horticulture as well. Refugee villagers, are thus regularly supplied with eggs, meat and fresh vegetables on a small scale. In Barawal and in Orakzai, all households of the sample were obtaining regular incomes, some generating far more than others.

The great majority earned income by working for local farmers or construction firms. Smaller groups were self-employed traders, craftsmen or businessmen. Others had found work within the public sector of the refugee villages, such as in dispensaries and schools. At the same time, a small part of the sample also obtained income through the regular sale of food relief. A few households seemed to generate funds on an irregular basis by selling off assets. On the whole, "income-generation was developed independently from refugee settings and it resulted from interaction between the refugees and the Pakistanis".

Concerning the economic and social links between the Afghan refugees and the local population, the refugee communities appeared to be centres of rapid growth with various connections to the local communities. Indeed, they made it possible for local farmers to expand their agriculture or to disengage their own labour and embark on more profitable activities, for instance, trading in urban Pakistan or construction work in Persian Gulf countries. The report notes, however, that in the local press more and more reports were appearing concerning the end of the construction boom in the Gulf and the possible return of large numbers of expatriate Pakistanis. It was also noted in the survey that at a village in Dir, the refugees themselves were involved in some charitable work with the destitute among the local population. At the same time, the more affluent among the local population supported the refugees in their localities in various ways. Simultaneously, controversies frequently arose between refugees and the poorer local groups concerning access to natural resources.

No relationship was found between the distribution of relief and a disinclination to engage in gainful activities. No refugee family of the 100 households interviewed in depth was found to avoid work as a consequence of being sustained free of charge by relief programmes.

In comparing the earlier and the present surveys it emerges that "where the traditional social structure is still at work in the refugee communities, food distribution appeared to be linked to prevailing social irregularities". In the two provinces, sample households showed a remarkable willingness to use their skills in order to make a living in a refugee situation. They also revealed noticeable resourcefulness in creating or searching for work opportunities in their own community or surrounding localities, as well as much further afield. The surveys also showed that the desertic ecosystem "continued on p. 19 
THE AFGHAN COMMUNITY in NEW YORK by Beth Jackendoff in the TRIBUNE (Queens) 5/9-15.

In a big white house with blue shutters at Santord Ave and 149th St., 70 oliveskinned girls, aged 6 to 15, sit closelypacked on a colorful Oriental rug. Their trousered legs are tucked neatly beneath them, and large diaphanous scarves called chodars drape their heads and shoulders. All are shoeless.

A man stands at the front of the sunny room in his stocking-feet. Behind him; a blackboard bears the Persian alphabet and a prayer written both in Persian letters and an English transliteration. In Farsi, a Persian dialect, the man tells the children that Afghan solidarity day, which is actually the Muslim New Year, is the following week, and he urges them to come to a demonstration that day at the United Nations to protest the Soviet occupation of Afghanistan. Suddenly switching to English, he says, "Repeat after me. Death to Communists.!"

In response, just at they have recited prayers in unison all morning, the giris chant, "Death! Death! Death!"

This is the Said Jamaluddin Afghani Madrasah School, a recently formed Sunday program for the children of the five to 6,000 Afghan immigrants who live in the New York metropolitan area. The house was acquired just three months ago and is also home to the Afghan National Islamic Council of Immigrants in America. The chairman of the council's Religion Committee, a man in his 50 s, dressed in a white shroud with a cap atop his white hair, is the mullah, or religious functionary. He teaches the boys across the hall from their sisters and is preparing a mosque downstairs. Already, a dozen men, some wearing turbans, sit on the floor of a darkened room just inside the house entrance, a pile of shoes and sneakers by the door.

"It's really hard to keep our religion and our heritage," says Habib Mayar, a tall man with a salt-and-pepper beary and a thick accent. "Some of our youngest are Americanized. For example, our kids know Halloween. They like Michael Jackson and the blue jeans." But now, thanks, to the community center, Mayar says "they learn the language, they remain Muslim."

Like many Afghans in New York, Mayar's life is a combination of hard work, religious and cultural pursuits, and political activism on behalf of Afghan refugees and the mujahidin, or freedom fighters, who oppose the Soviet troops and Soviet-backed regime in Afghanistan. His business, Liberty Food ("I love liberty," he says, "l'm fighting for liberty") is a supply house for the many fried chicken stores run by Afghans around New York. But the garage of his Jamaica office is also filled with cartons of food and clothing destined for the mujahidin in Afghanistan, and refugee camps in Iran and Pakistan,

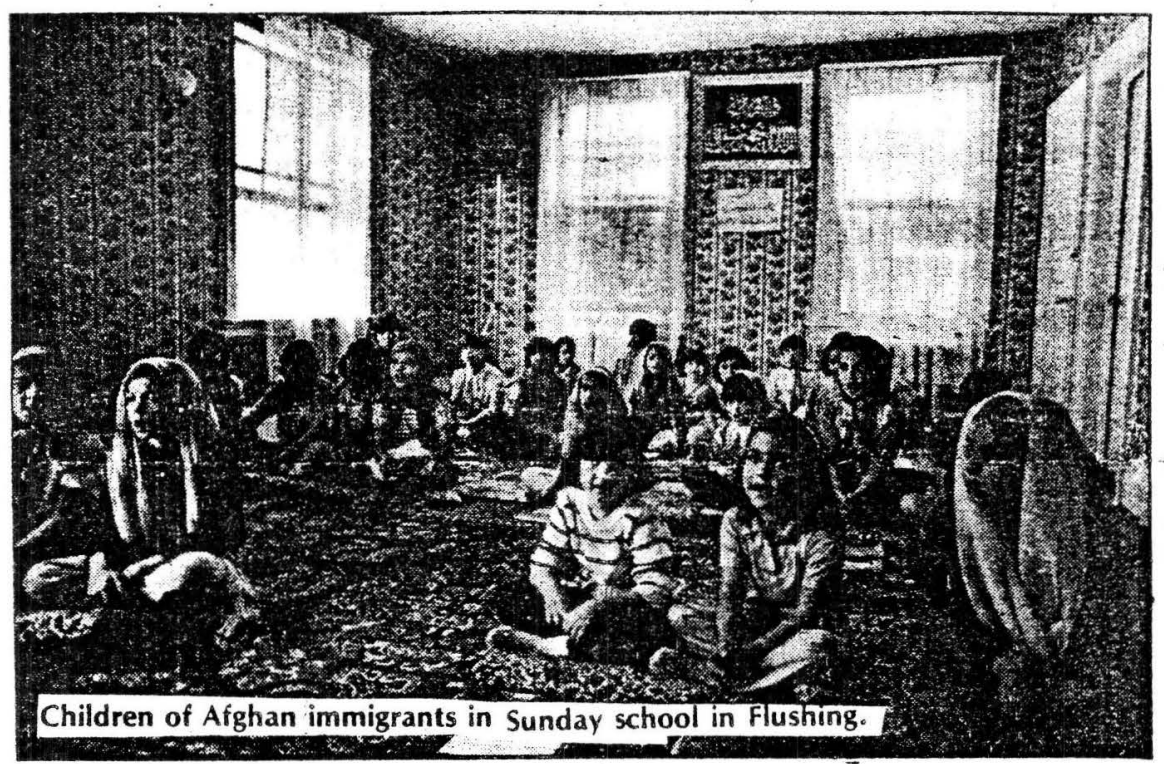

home to four million Afghans who have fled their country's turmoil. He opens one of the boxes piled high in the garage to reveal dozens of bottles of spirulina, a high-protein vitamin, and from a huge plastic bag full of clothes he pulls out a pair of tiny red sneakers. "Pretty good stuff, huh?" he says smiling.

As chairman of the Afghan Community in America, Mayar arranges the shipping of goods from their donors all over the U.S. to his warehouse, from which he sends them overseas any way he can. For example, Swissair will soon fly 2,000 pounds of medicine to Geneva free of charge, and Mayar is arranging its transportation from there to the Afghans.

Another leader in the Afghan community. in New York is "Chicken" Zia, so called because he was the first Afghan to open a chicken store. He now owns seven, some of them franchises of the Kennedy and Kansas fried chicken chains. He uses his business to employ newly-arrived Afghans. "I remember in 1971 when I first came here," says Zia, a tall, reserved man, "the only job I could get was in a factory... And I know a lot of people, they worked in Afghan Airlines. But they can't get a job at Pan Am. Maybe they have a degree, but when they come here, they can't get a good job.

"Now in my stores, we can give them a job without any problem," he continues proudly. "You don't ask them, "do you have any experience?' We put them in the front of the store to be with people, to learn English. And now they know English."

Why chicken? Marie Sherza, who is Mayar's secretary, says, "Americans like chicken. And it's cheap."

And $\mathrm{Zia}$ believes his chicken is better than most. "We have a different recipe," he confides, without divulging the secret ingredients.

A féw blocks away from Liberty Food, Ahmed Fahim, 25, and Mohammed Farid,
24. man the kitchen and counter at New York Chicken. "We work here because nobody else gave us good jobs," says Fahim. "We don't like to go on welfare." But the high cost of living in New York and the crime worry him. He has a wife who can't speak English and an 8-month-old daughter. Even with his job, he says he doesn't have enough money put aside to support himself for a week. "And you can't trust nobody in New York, it's not safe," he adds.

Affectionately, Mayar takes Fahim's hand and playfully slaps the young man's face. "That's just human nature," he says philosophically. "There are criminals all over the world. You find a good Muslim or a bad Muslim, a good Christian or Jew or a bad Christian or Jew." He shrugs and adds, "Just like that piece of chicken is good, but that piece is bad."

Farid is equally optimistic. "You can do anything you want here." He hopes to continue his education at some point, and says of Americans, "They like foreigners."

Marie Sherza, Mayar's secretary, agrees. She has a daughter, 10, whom she sends to a Catholic school, and a son, 4 , who goes to a private Jewish school. "They have no problem being accepted by other children," she reports. And she isn't worried about sending them to parochial schools, which she prefers to public schools because they are stricter. "As long as they know they are Muslims, it's okay," she says. "Afghan parents try their best to grow them up our way. At home, they speak their language, they're Afghan. And out in the street, they're pure American."

The children's Sunday classes cover Afghanistan's politics and history as well as Sunni Muslim traditions and Farsi and Pushtu, two Persian dialects. Adina Fazelyar, 12, who came to the U.S. from Kabul, Afghanistan's capital, four years ago, proudly showed a visitor to the class a notebook full of assignments she completed 
in Persian. She explains that when they read from the Koran, the Muslim scriptures, "you have to cover your head. And you're not allowed to leave your sleeves open, but 1 forgot," she adds tugging her long scarf over her bare arms. "I would like to go back to Afghanistan," she says, echoing the sentiments of many adult Afghans, "but they're fighting there."

Homa Wahidi, 14, who came from Kabul four years ago, agrees. "When I remember my friends or grandparents in Afghanistan, I feel like crying," she says. "I wish I could go back."

"I wish I was big, I would go with you," exclaims 13-year-old Homa Rashidzada. "Everytime you think of it, how people live there, we are living in luxury here. I don't think we are doing enough to help. We talk about it, but you have to take action." She is looking forward to the anti-Soviet demonstration, and points to a picture in her workbook of a young boy, about 10 , holding a rifle. "They do become soldiers at that age. The ones who can't leave have to fight."

"Did you see the lady on T.V. who tells the future?" asks her friend Homa Wahidi. "She said the Russians would leave Afghanistan soon. And maybe then we can go back."

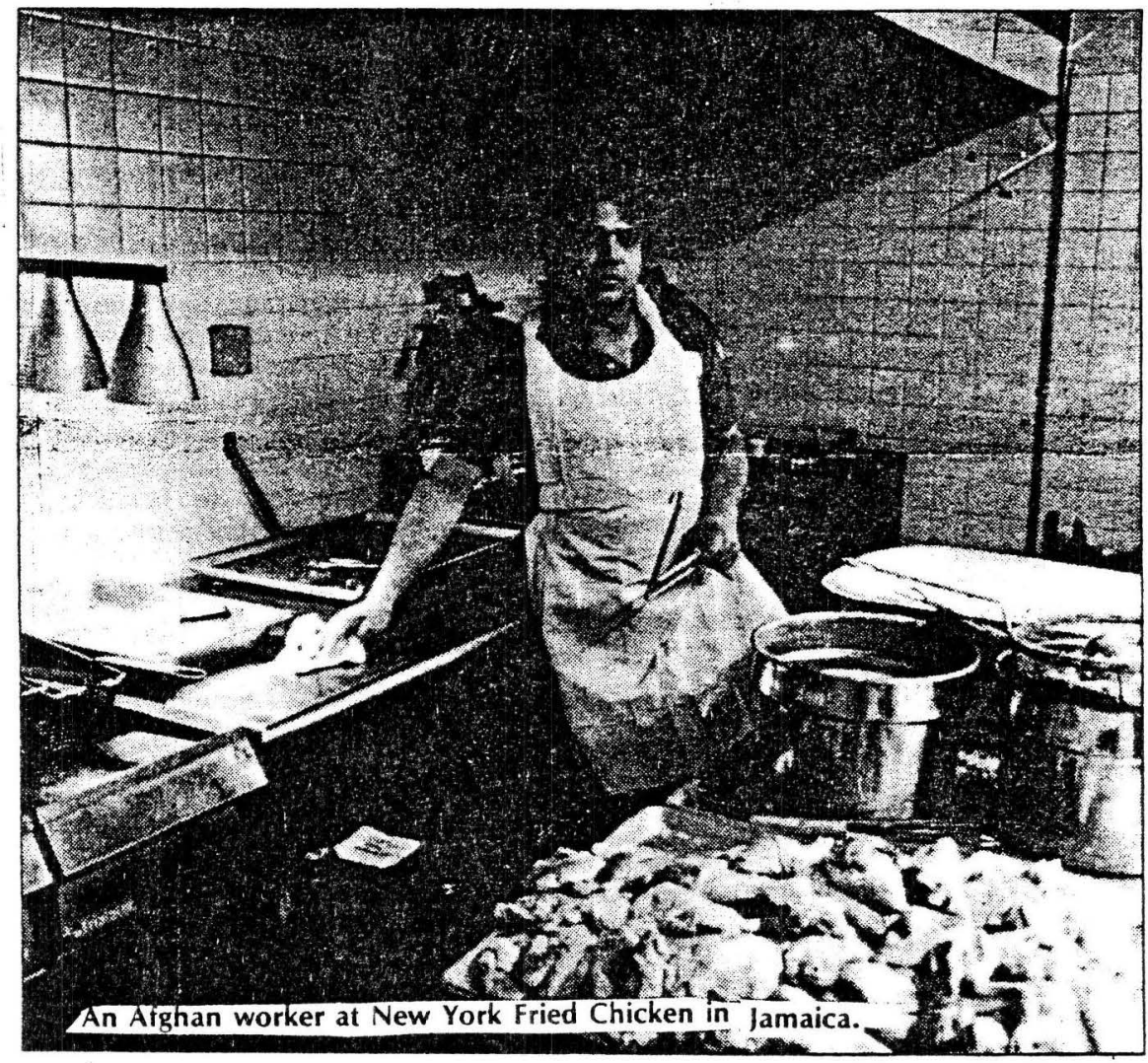

\section{SELF-RELIANCE continued from p. 17}

of the research areas in Baluchistan implied more limited opportunities for gaining a livelihood independently from external relief aid.

"The findings reveal that the refugee communities in the frontier are changing and that some refugee populations have already had the experience of fending for themselves for a limited period". As a consequence, Hanne Christensen suggests various ways to adjust in a flexible manner the distribution of relief and food items to take into account these changes. She proposed four options. One is "to reduce gradually the supply of all donated relief items; another to cut out completely the supply of any donated non-food relief as, for example, footwear and household utensils, while maintaining a full supply of food items for the time being. A third option is gradually to phase out distribution of all items to some groups while maintaining it in full for a further period for others. A fourth option is to eliminate completely part of the non-food items and reduce certain food items for the bulk of the target population, while maintaining full distribution of all items for minor groupings for some time".
In regard to these options, Tom Barnes of UNHCR's South-West Asia Section, comments: "UNHCR since 1983 has endeavoured to progressively reduce that portion of the assistance budget for relief and services, while increasing funds for selfreliance. Distribution of footwear is now essentially reduced to children enrolled in school. As for Ms. Christensen's third and fourth options the phasing out of distribution to some groups, while maintaining it for others - we are at a loss to discover a rational way to proceed. We do not wish to create a situation whereby vulnerable groups of refugees, such as widows with minor children, might end up with insufficient supplies."

Ms Christensen further suggests various income-generation and vocational training schemes for men and women. She also proposes, among a score of other suggestions, the setting-up of "ante-natal and underfive clinics which would help in the collection of data on health and the levels of living, including nutritional conditions, for the management of the refugee operation".

The author of the report concludes that the creation of self-reliance at household or community levels ap- pears appropriate only as a shortterm measure and suggests a longer perspective. But, in the part of the report dealing with the Afghan refugees' perspective of their own situation, she points out that "refugees were unanimous in the belief that their future lay in repatriation and that their stay in Pakistan was of an interim nature".

\section{EKBER MENEMENCIOGLU}

AFGHAN UPDATE, the weekly bulletin of the Federation for American Afghan Action, 236 Massachusetts Avenue, NE, Suite 603, Washington, D.C. 20002, has a new editor. Spencer Lee replaces Matthew Erulkar. Matthew is now working with the Afghan Support Team \& the Center for Liberation Studies \& Guerrilla Warfare.

AFGHAN UPDATE can be had for the rest of 1985 for $\$ 45$. 


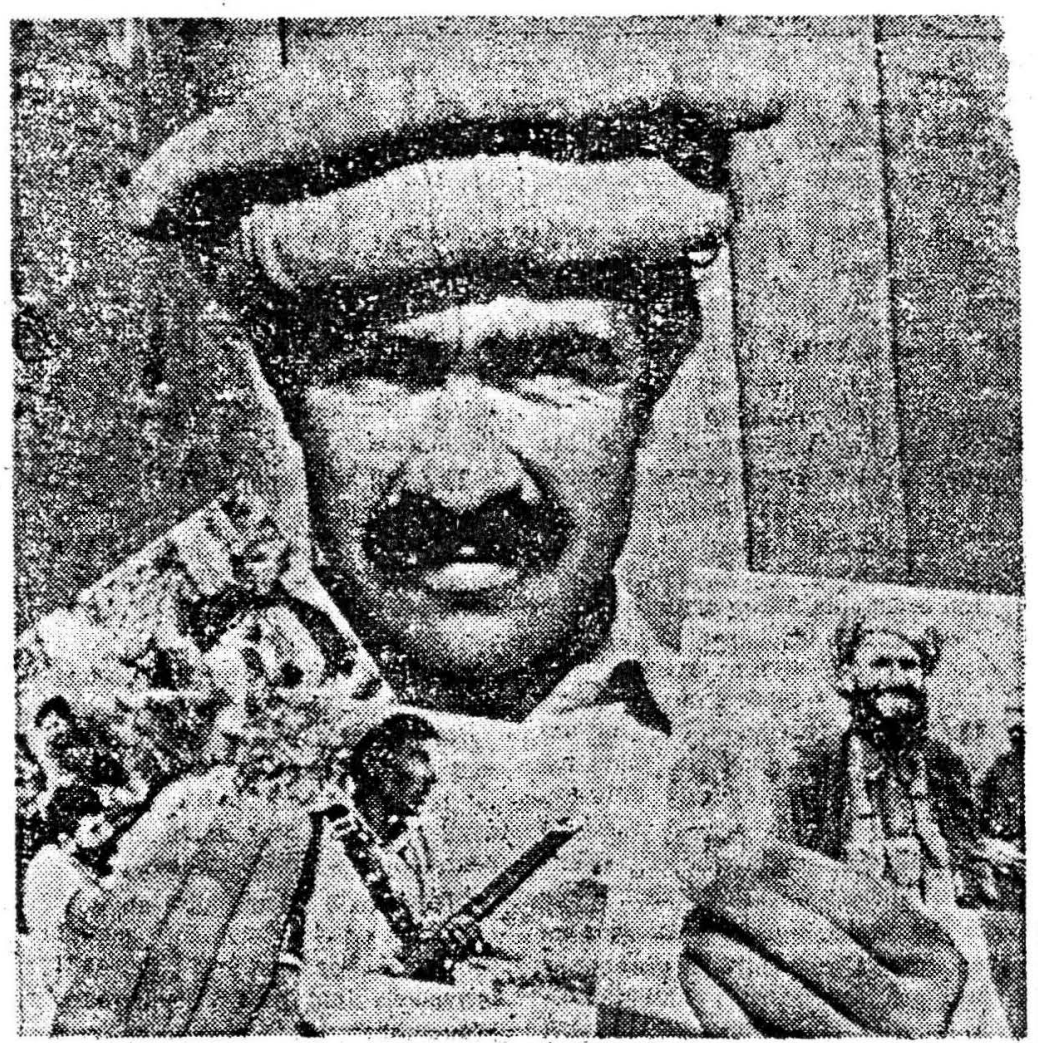

E. Joseph Deering / Chronicle

Abdul Wahab Kamaf; a Houstonian and native of Afghanistan, displays photographs he took of Afghan resistance fighters during a recent visit to his homeland. Kamal spent six months traveling with small groups of fighters, known as mujahedeen.

\section{Afghan recounts pain of Soviet occupation}

BY REBECCA TROUNSON

Houston Chronicle

Were it not for his American wife In fact, he would still be there, joinWdul What ing them full time in their battle Abdul Wahab Kamal would still be in ganst the Soytet troons if it were not

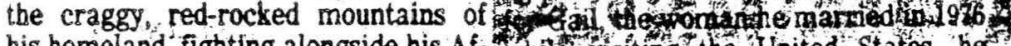
his homeland, fighting alongside his Af- while visiting the "United States, he

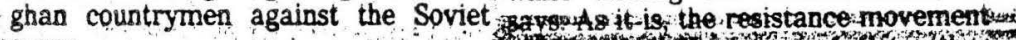
army.

Much of his beart is still there.

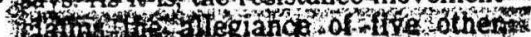
males in his immediate family - in Kamal, who has just returned to his cluding his white-bearded, 85-year-old home in southwest Houston after six father - and many other relatives. months in Afghanistan, makes no pre- Kamal, 36, sits against the wall of his tense of hiding either his passionate living room, a wall that itself speaks nationalism or the hatred he feels for eloquently of his two lives. Two framed the Soviets who marched into his coun- photographs of equal size adorn it: one try in December 1979.

"They will have to kill all the Afghans, the entire population, to win this war," he says, his voice rising with emotion. "If there is even one Afghan left, he will fight them until he dies or kicks them out."

Hours after he reached home Friday, Kamal sat in his living room and spoke of the trip his second lengthy visit to his country since 1981. Propelled by a desire to see his family and an even bands of guernillas, or mujabedeen, taking part in some operations against Soviet troops and observing many others.

In early July, he entered Afghanistan from Peshawar, a Pakistani city that borders the country. Kamal said he was met in Peshawar by Amin Wardak a guerrilla commander who is his cousin. Wardak, Kamal said, leads between 2,000 and 2,500 men in the area of northeastern Afghanistan that bears the same name.

Once inside, Kamal found a country far different from the one he left in 1981, when he spent four months with the resistance: "Very proudly, I can'say their morale, their pride, is much bigher now than four years ago," he said. "They are much more organized than before."

Kamal, who in his home wears Afghan clothes - sandals, a soft woolen cap and baggy, cotton trousers and shirt - believes that the guerrillas and their supporters now control 95 percent of the country, with the Soviets struggling to hold the capital city of Kabul and a few outposts.

And he smiles as he says the resistance is gaining strength, fueled by what he says are the Soviets' oppressive tactics.

"When they go to any area, the Russians destroy everything," he said. "They destroy the crops, the agriculture. When they see any animal, large or small, they are killing that. They go into the villages in their tanks and they kill the people there - men, women and small children."

He told of a time he and his group of fighters were in a village just off the nrair highway between Kabul and the

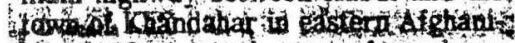
stan. A Soviet tank, part of a column mexing toward Khandahar, ran oxer a firie and four soldiers were tilled $\mathrm{Ka}$ "mal said."

"There were 20 or 25 small civilian buses waiting for the tanks to pass," he said. "After the tank exploded, the Russians start shooting on the buses. They killed 63 people with their shooting."

In return, Afghan guerrillas later blocked a highway, capturing and de stroying 13 Soviet tanks.

Kamal says the war against the Soviets has become a jithad, an Islamic holy war.

He points to a picture of his father, a white-bearded, wizened old man with a rifle and ammunition belts slung around his shoulders. "He is fighting, too," he says.

For the moment, Kamal says he is glad to be home, happy to return to his wife and his quiet life in Houston, where he buys and sells small grocery stores. But he says be will return to Afghanistan again soon, to fight alongf side his family and friends.

it "There is no reason for the Russians to fight this endless war, be saids "1. They will lose it. It's best if they just leave the country."

January 26, 1985

Houston Chronicle 
Question. Who qualifies for asylum?

Answer. Under the Refugee Act of 1980 , an alien may qualify for asylum if he has "a well-founded fear of persecution" in his homeland "on account of race, religion, nationality, membership in a particular social group, or political opinion." It is common to speak of political asylum, but the law does not restrict asylum to cases of political persecution.

Q. How many people get asylum?

A. The Immigration and Naturalization Service granted 8,278 applications and denied 32,344 last year as it made a major effort to reduce its backlog of cases. Most of the successful applications came from citizens of Iran $(5,017)$, Nicaragua $(1,018)$ and Poland $(721)$.

Q. What is the difference between asylum and refugee status?

A. The standards are virtually identical. But a refu_t gee seeks admission to the United States from a third country outside his homeland. By contrast, to apply for asylum, an alien must already be in the United States or at a port of entry.

Q. Do aliens have a right to asylum?

A. Aliens have a right not to be returned to countries where they would face persecution. But this does not mean they have a right to permanent asylum in the United States. The Refugee Act of 1980 says that aliens with a well-founded fear of persecution "may be granted asylum in the discretion of the Attorney General." Thus, the Supreme Court has said, aliens who qualify for asylum are not automatically entitled to it.

Q. In practice, how does a person show a wellfounded fear of persecution?

A. Congress did not specify the evidence required, and courts to date have not agreed on a description of the standard. Courts have said that there must be "objective facts" to support an alien's subjective fears of persecution. This might include testimony that an applicant would face danger in his homeland or that other people there had suffered persecution for similar reasons.

\section{Q. What else does the Government require?}

A. The alien must present "specific facts" tending to show that he will be singled out for persecution. The fact that a person might be injured in civil strife or violence in his homeland is not enough. Like the Carter Administration, the Reagan Administration contends that many people who come to the United States from Central America are fleeing poverty, not persecution, and therefore do not qualify for asylum. Experts on refugees say that aliens often have a combination of motives.

Q. Who decides whether to approve an application?

A. Officials of the Immigration and Naturalization Service, an agency of the Justice Department. For every application, they must seek a formal advisory opinion from the State Department's Bureau of Human Rights and Humanitarian Af $f_{7} i:$

Q. Is the Reagan Administrittion considering changes in the rules?

A. Yes. One of the propised changes says an alien could be denied asylum if he passed through a country where he could have obtained "safe haven" en route to the United States. American of ficials contend, for example, that Salvadorans could have stopped off in Mexico and that some of the Afghans who reach this country could have stayed in Pakistan. The proposed rules are to be issued for public comment this summer.

\section{Knocking at the door}

Requests for asylum in the U.S. (fiscal years)

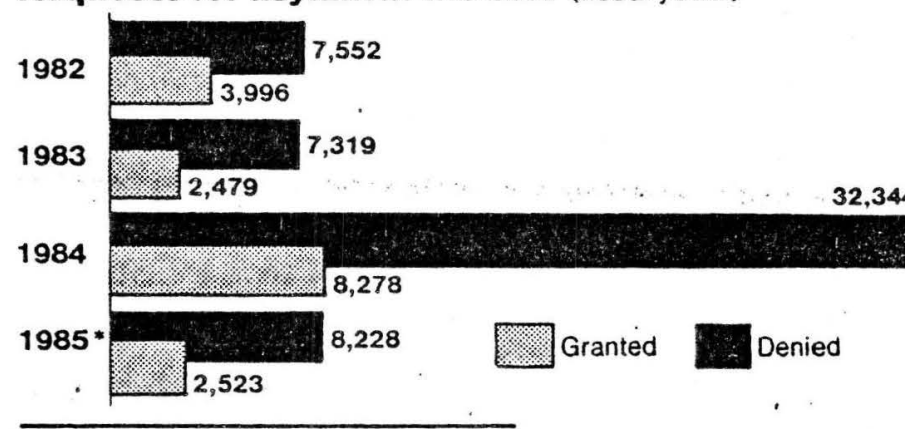

\section{Largest groups of applicants}

1982

1983

1984

1985*

Granted Denied Granted Denied Granted Denied Granted Denied

\begin{tabular}{|c|c|c|c|c|c|c|c|c|}
\hline Afghanistan & 283 & 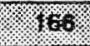 & 53. & 27. & 1366. & 260. & 33 & , \\
\hline El Salvador & 69 & 1.067 & 11 & 2.914. & 1928. & 16045 & $47 \%$ & 1428 \\
\hline Iran & 2610 & 6063 & 760 & 567 & $6 \% 17$ & 3.26 & $666 \%$ & 1.644 \\
\hline Nicaragua & 386 & 950. & 94 & (3, 346 & 1.018 & 274 & 102 & 24448 \\
\hline Poland & 102 & 18095 & 261 & 900 & $12 \%$ & 4482 & 235 & $3: 2$ \\
\hline
\end{tabular}

-through February

Source: Immigration and Naturalization Service

\section{Afghan brothers to get asylum in W. Germany}

SEOUL - Two Afghan brothers who arrived in South Korea after an around-the-world search for political asylum will be sent to West Germany later this month, Foreign Ministry officials said
Monday.

They said the West German government had decided to receive half-brothers Amanullah Roashan, 24, and Amanullah Obaidayi,
17 , as refugees.

The two first tried to enter the United States illegally from Pakistan via Sri Lanka, after which they requested U.S. asylum and spent 10 months in a New York jail. In March their request was denied and they were deported.

Korean Air Lines then flew them to Taiwan, Hong Kong, Sri Lanka, Saudi Arabia and Thailand but no government would let them in, according to a New York human rights group. They have been in a refugee camp in South Korea since April.

$$
\text { NY Tribune } 6 / 21
$$




\section{'PRESS NOTES $3 / 31$ Vol I $\# 2$ \\ Afghanistan}

Editorials and commentaries on Afghanistan have abounded over the past few months: the fifth anniversary of the Soviet invasion drew derogatory mention on the editorial pages of many, very probably most, major daily newspapers in the United States. Nor has the abuse of human rights by the Soviets and government forces in Afghanistan gone uncondemned of late in the U.S. media: the Helsinki Watch Report. Tears, Blood and Cries (published December 1984), based on interviews with Afghan refugees in Pakistan, and the reports of various European medical and media workers have been cited in newspaper editorials and columns as evidence of widespread violation of human rights.

Rather curiously, however, there has been a dearth of critical discussion of the growing U.S. role in arming and financing the insurgents in Afghanistan.

Soldier of Fortune, the mercenaries' monthly, has of course long advocated assistance to the rebels, and its readers are regularly provided with opportunities to send help themselves. Other conservative voices which are frequently proponents of U.S. intervention have favored still more aid to the Afghan rebels. Malcolm $\mathrm{S}$. Forbes, Editor-in Chief of Forbes magazine, recently complained that journalists who have visited Afghanistan report that "armed Russian helicopters are the biggest menace. How come we haven't supplied 'em with some of the mobile-infantry type weapons that are supposed to make choppers keep their distance?"

He continued with a note of petulance, "Our choppers get shot down Central America -- presumably by Russian arts to see if they work? If we don't, it's appalling. If we have such weapons, how better swiftly somebody in the Pentagon morass alling. Until we do, let's see how that matter. get hold of a few of morass can borrow some from the Israelis. Or, for "In any way, get some into Afghanistan the Reds have got. $[8,21]$

While the proponents for intervention are urging the Reagan administration on, the somewhat skeptical of if not always unopposed indochina debacle have generally been wars) have maintained a near silence on the subject of support involvement in foreign mujahidin. The Los Angeles Times has the subject of support for the Afghan recent editorial that $n$ he large-scale U.S. military aid to the come to take a very serious look at whether or for that matter, in the long term inter guerrillas is in the American interest -. (LAT 2/4/85) $[7,11]$

Even more striking than the lack of questioning by the mainstream media has been the virtual ignoring of the issue by significant voices to the left of center, which are debate. A salient example of this blindness toward the issue of U.S. policy toward Afghanistan is Jack Newrield's "Cry for Afghanistan". (Voice $1 / 22 / 85)[4,16]$ Jack Newfield is quite right in pointing out the atrocity of the Soviet invasion and occupation of Afghanistan, and deserves due credit for bringing the report of Helsinki Watch to the attention of Voice readers.

But it is not until Newfield is halfway through his piece that he turns to "the hard political question" of "what is the appropriate response to this calamity?" He asserts that "I certainly do not advocate American military, or CIA,

intervention." His casual dismissal of the intervention option could easily mislerd readers into believing that the U.S. is not currently engaged in such activity, and that Newfield merely wants us to know that he would not propose taking such an initiative.

In fact, Congress has approved expenditure of some $\$ 250$ million by the CIA this year for covert operations on behalf of the Afghan insurgents: for a sense of the order of magnitude of this program, consider that it is more than ten times the size of the aid to the Nicaraguan contras; it constitutes 80 percent of the CIA's budget for covert operations in fiscal year 1985; and it has become the largest clandestine U.S. intelligence operation since the Indochina war. While the 1985 appropriation is the largest thus far for the Afghan guerrillas, and includes gifts of sophisticated weaponry -- armor-piercing anti-aircraft cannon, costing about $\$ 1$ million each, including ammunition and delivery -- it is hardly the first assistance the U.S. has sent them. U.S. aid to the guerrillas is estimated to have totalled some $\$ 400$ million in the first four years after the Soviet invasion.

The most extensive report on the U.S. covert assistance to appear in the U.S. press thus far is a piece by Bob Woodward and Charles R. Babcock in the Washington Post on January $13:[4,2]$ perhaps Newfield had written his article before seeing their report, but if he had been following the news on Afghanistan with any care, he cannot have missed seeing reports of the massive U.S. covert assistance, including the huge figure projected for 1985.

Nonetheless, Newfield writes: "Intellectually, the response to Afghanistan should be a single standard of judgment. Since I argue against all American military intervention in Central America, I also argue against Russian tanks in Kabul." An impeccable sentiment, Mr. Newfield, and one I share.

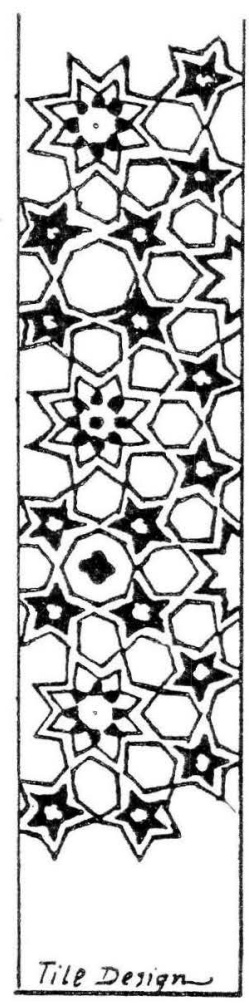


Two items from the SOVIET NATIONALITY SURVEY

\section{- ESTONLA}

The second issue of a new Estonian samizdat publication, Self-letter, contains an interview with a demobilized Estonian soldier who served in Afghanistan in 1981-82. Excerpts follow below:

"In the smaller villages everyone who came before us was to be shot. Villages in Afghanistan are completely different from our Estonian villages. First of all, they are much more populous. Houses are attached to other houses; the village is like a clay labyrinth with small houses and inner courtyards. It is difficult to orient yourself, and you never know what awaits you behind the next corner.... Before you proceed into a side street or courtyard, you must fire a volley into dark corners. Only then may you jump inside. Similarly, with regard to controlling houses, first a burst of gunfire, then you enter yourself.... In such villages there is a lot of blood. A village can hardly sustain life after this....

"For a general punishment operation, the tactics are basically the same.... All, even slightly suspicious, individuals were to be shot immediately. Generally, all men who appeared capable of fighting were considered suspect.... Similarly, all those individuals whose appearance aroused suspicion [were shot], for example, people clothed in chadors, which are generally worn by women, although men. can also go about wearing them. A chador covers the face, and so it is easy to conceal oneself... Those who began to run or tried to hide in any way were immediately shot. These requirements were made clear to us before the beginning of operations" (RFE$\mathrm{RL}, 4$ Jan. 85).

$4 / 85$

\section{UZBEKISTAN}

- Uzbekistan, claims M.G. Pikulin, is "participating actively in the implementation of profound transformations in the socio-economic life of Afghanistan, in the development of the national economy of our southern neighbor, and in the successful resolution of the urgent tasks of the April Revolution of 1978" (Obshchestvennye nauki v Uzbekistane, No. 8, 1984). Uzbek "enterprises, organizations, and specialists" helped build and equip cottoncleaning plants, a fertilizer plant, an irrigational system, an industrial-irrigational complex in Jalalabad, a hydro-electric power station in Pul-iKhumri, and a thermal energy power plant in Mazar-i-Sharif. Uzbek-Afghan trade is also growing. Uzbekistan exports transport, electro-technical, and electronic equipment, a variety of machines, compressors, chemical, light, and textile industry products, tractors, and cotton-growing and cottonginning technology. Aside from "a large group of Afghan boys and girls studying in the educational institutions of $\mathrm{Uz}-$ bekistan and especially in Tashkent," Pikulin doesn't mention any Afghan exports.
MIDEAST

UPDATE

continued
But why not posit another parallel? If you object to U.S. covert aid to the Nicaraguan contras do you also object to assistance to the Afghan rebels? I do, partly for general reasons -- opposition to U.S. military intervention anywhere. direct or indirect, and alarm at seeing the CiA rebound so quickly from its setbacks in the 1970's and put ita covert operations division into high gear once again. But there are other, special, reasons why the ClA's Afghan caper is an especially cynical one:

1. The covert assistance program is rife with a corruption that strengthens very undemocratic forces. Matthew D. Brulkar of the Federation for American Afghan Action, a Washington lobby for the rebels, estimates that only about an eighth of U.S. aid over the last four years has reached the guerrillas. While the Afghan groups themselves, according to dispatches from reporters who visited them in Pakistan or travelled with them within Afghanistan, hardly appear untainted by corruption, the major diversion in the pipeline seem to be Pakistani. Most aid to the guerrillas goes through the blood-stained hands of the Pakistani despot Zia ul Haq, and a lot of it seems to be sticking to fingers. Frederick Kempe, a staff reporter for the Wall Street Journal wrote recently from Pakistan that "there is widespread suspicion that the Pakistan government siphons off the best of the weapons intended for the Afghan resistance" by the U.S. [1,20] An apparatus of repression like Zla's is hardly something which ought to be reinforced in the name of succoring freedom. 


\section{DOCTORAL DISSERATIONS ON AFGHANISTAN}

from Doctoral Dissertations on Asia, Vol. 7, \#1 1 \& 2 (winter/Summer 1984), compiled \& edited by Frank Joseph .... Shulman for the Association for Asian Studies (published in Jan. 1985).

ALEKUZEI, Gholam Rabani. Bedürfnis- und arbeitsorientierte Ausbildung technischen Produktions- und Lehrpersonals am Beispiel Afghanistans. [German: The Training of Technical Personnel for Production and Education, Geared toward Needs and Work: Exemplified by Afghanistan.] Fernuniversität Hagen, 1983 (Dr.). 326p. For copies, write to the Fernuniversitäcsbibliothek, D-5800 Hagen, West Germany.

ALLEN, Terry Arden.

Timurid Herat. Harvard, 1981 (Ph.D. in Fine Arts). 1, 259p. Available at the Harvard University Archives, Pusey Library, call no.HU 90.11500 .80 .

BARTON, Laurence.

The American Olympic Boycott of 1980: The Amalgam of Diplomacy and Propaganda in Influencing Public Opinion. Boston University, 1983 (Ph.D. in Journalism). 181p. DAI 43, no.12 (June 1983): 4030-A; UM 8309745. Focuses on the U.S. Government's call for a boycott of the XXII Olympiad summer Games in Moscow in retaliation for the Soviet invasion of Afghanistan in 1979.

DOR, Rémy.

"Si tu me dis: chante! chante:..." Documents pour servir à la connaissance de la tradition orale des Kirghiz du Pantr Afghan. [French: "If You Tell me: Sing! Sing!..." Documents for Understanding the Oral Tradition of the Kirghiz of the Afghan Pamir.] Paris III (Sorbonne-Nouvelle), 1980 (Doctorat d'Etat ès lettres). 963, 251p. A copy is available at the Bibliothèque de la Sorbonne, library catalogue no.W 1980 (175 1-4)-4\%.

GHANI, Ashraf.

Production and Domination: Afghanistan, 17471901. Columbia, 1982 (Ph.D. In Anthropology). xxiv, 448p. Copies will eventually be available chrough University Microfilms International.

GOPALAKRISHNAN, R.

Political Geography of a Land-Locked state: A Case Study of Afghanistan. Jawaharlal Nehru, 1979 (Ph.D., School of International Studies). xx, 364p. For copies, write to the Librarian, Jawaharlal Nehru University, New Mehraul1 Rd., New Delhi-110067, India.

NAD̄Z̄

Kimmeridy Severnogo Afganistana. [Russian: The Kimmerids of Northern Afghanistan.] Moskovskil gosudarstvenny 1 universitet imeni $M$. V. Lomonosova, 1980 (Kandidat nauk in Geological and Mineralogical Sciences). On the geology of Afghanistan during a period at the end of the Jurassic.

NAZAROV, Khaknazar.

Narodnyi $i$ prosvetitel'sko-antifeodal'nye dvizhenila $\vee$ Afganistane (konets $X I X$-nachalo $X X \vee$.). [Russian: The National and Enlightened Anti-Feudal Movenents in Afghanistan (From the End of the Nineteenth to the Beginning of the Twentieth Century). I Moskovski1 gosudarstvennyi universitet imeni $M$. V. Lomonosova-Institut stran Azi1 1 Afriki, 1978 (Doktor nauk in Historical Sciences).
RANDZHBOR, Basir.

Bi udzhet Afganistand 1 ego rol' $v$ khoziaistvennokul'turnom razvitil strany. [Russian: Afghanistan's Budget and Its Role In the Economic and Cultural Development of the Country.] Kievskil institut narodnogo khoziaistva imeni D. S. Korotchenko, 1978 (Kandidat nauk in Economic Sciences).

TAB̈B̈, Lacif.

Die afghanische Landreform von 1979: ihre Vorgechichte und Konsequenzen. [German: The Afghan

schichte Reform of 1979: Its History and Consequences.]

Freie Universität Berlin, 1981 (Dr.). 236p. For copies, write to the Frele Universitat Berlin, copies, write to the stelle, Garystr. 39, D-1000 Berlin 33, West Germany.

THEWALT, Volker

stützelemente und ihr Schmuck in der Architektur der Kuṣăga-zeit. [German: Supporting Elements and Their Decoration in the Architecture of the Kusana (Kushan) Period.] Bonn, 1980 (Dr., Philosoph 1sche Fakultät) . 111, 339p. \& 274 1llustrations. For copies, write to the Universitätsbibllothek Bonn, Postfach 2460, D-5300 Bonn 1, West Germany.

\section{ZAFARI, Salam.}

Geologo-mineralogicheskie predposylki $i$ metodika poiskov mestorozhdenit zolota (rudnykh i rossypnykh) $v$ oblastiakh Takhar i Badakhshan (severo-vostochnaia chast' Demokraticheskoi Respubliki Afganistan;. [Russian: Geological and Mineralogical Preconditions and Methods of Finding Deposits of Gold (Ore and Alluvial Deposits) in the Badakhshan and Takhar Regions (Northeastern Part of the Democratic Republic of Afghanistan).] Moskovski1 geologo-razvedochnyi institut iment $\mathrm{S}$. Ordzhonikidze, 1979 (Kandidat nauk in Geological and Mineralogical Sciences).

\section{NEW ALLIANCE}

The alliance formed on $5 / 17$ between the the two major Peshawar alliances consists of Mujaddedi, Nabi \& Gailani from the "moderate"Jebha, Harakat Inqelab \& Mahaz parties \& Khales \& Hekmatyar from the two Hezb Islami parties, Rabani from Jamiat \& Sayaf from Ittehad. In a press conference, Mr. Hekmatyar, acting as spokesman for the group, said, "We are already coordinating our war efforts inside Afghanistan \& intend to seek representation on various international fora such as the UN \& the Organization of Islamic Conference. Officers of "The Islamic Unity of Afghan Mujahideen" will be elected later.

$$
\text { AICMB \#50 5/85 }
$$


EVENTS - Past, Present \& Future

The British Afghan Refugee Information Network lists 2 events in the British Isles. Sandy Gall gave an illustrated lecture on $6 / 21$ at Stonewall House in Chiddingstone, Kent. An AFGHAN DAY will be held July 7 at the Farmland Museum, Haddenham, Ely, Cambridgeshire. For details call (0353) 7405777.

The fall lineup of ASSOCIATION FOR ASIAN STUDIES CONFERENCES follows. The program chairmen are also listed. Contact them if you have suggestions or resources for panels on Afghanistan.

October 4-5 - NEW YORK CONFERENCE at the Rochester Institute of Technology.

Richard Chu, Dept. of History, Rochester, NY 14623.

October 11-12 - WESTERN CONFERENCE in

Long Beach. Arnold Kaminsky, Asian Studies Program, California State Univ., 1250 Bellflower Blvd., Long Beach, CA 90840 .

October 11-13 - MIDWEST CONFERENCE at Miami University. Gilbert Chan, History Dept., Oxford, OH 45056.

October 19-20 - NEW ENGLAND CONFERENCE at Wellesley. William Joseph, Dept. of Political Science, Wellesley, MA 02181. October 25-27 - MID-ATLANTIC CONFERENCE in Washington. Josef Silverstein, Dept. of Political Science, Rutgers Univ., New Brunswick, NJ 08903.

October 31 - Nov. 2 - SOUTHWEST CONFERENCE at Hot Springs, Arkansas. Eugene Corcoran, Dept. of History, Univ. of Central Arkansas, Conway, AR 72032 .

January 17-18, 1986 - SOUTHEAST CONFERENCE in Raleigh. Jonathan Goldstein, Dept. of History, West Georgia College, Carrollton, GA 30118.

March 21-23 - AAS ANNUAL MEETING at the Chicago Hilton. Robert Tilman, P.0. Box 5036, North Carolina State Univ. , Raleigh, NC 27650.

The MIDDLE EAST STUDIES ASSOCIATION will hold its annual meeting at the Hyatt-Regency Hotel in New Orleans Nov. 23-26. Get information from MESA Secretariat, Dept. of Oriental Studies, Univ. of Arizona, Tucsion, AZ 85721 (602/621-5850).

November 1-3 - 14th ANNUAL CONFERENCE ON SOUTH ASIA at the University of Wisconsin. For Information write the South Asian Area Center, 1249 Van H1se Hall, UnIv. of Wisconsin, Madison, WI 53706 (608/263-5839).
AFGHANISTAN: COMBAT D'ESPOIR was the subject of a colloquium sponsored by the PREP HECI Groupe Afghanistan held in Paris on May 9. Organizations taking part were Aide Medicale Internationale, Medicins De Monde, Medicins Sans Frontieres, Afrane, Amafaf, Bureau International Afghanistan, Guilde Du Raid \& Amnesty International. Topics discusses were the resistance, the refugees \& the impact of the media on the Afghan situation.

George Collins of Wichita State University presented a paper on "Military Developments in Afghanistan Since the Soviet Invasion" at the KANSAS HISTORY TEACHERS ASSN annual meeting on $3 / 20$ in Pittsburg, Kansas.

Leon Poullada spoke on Afghanistan at Wichita State University on 4/23 on "Afghanistan's Resistance to Soviet Domination." The University's paper.THE SUNFLOWER carried a report of Poullada's speech which concluded:

Their - sense of honor comes from Islam, he said, adding that children's religious convictions are passed on to them by their mothers.

Because of their faith, he said, the guerrillas are a formidable foe.

"Death in battle, to an Afghan, is an honor, a highest honor," he said. "Especially if it is in defense of his tribe or his family, or best of all, if it is in defense of his religion, for Islam."

Added to the strong family ties and religious fervor, Poullada said, is the state of mind Afghans have, which helps them immensely. For one thing, he said, the Afghans regard Soviets as "atheistic coiffures." [ hairy Kafirs?!. . Ed.j

He also said that the Afghans have a different sense of time than do westerners or Soviets. He explained that the Afghan people have been invaded and conquered 16 times, and their country has been occupied for periods of more than 100 years.

Still, in the minds of the Afghan people, they have never been conquered, he said. Thus, he said, they are not overly concerned about a five-year occupation.

"In their minds, they have never been conquered, and never will be conquered," he said. $\quad 4 / 26$

AMNESTY INTERNATIONAL held a forum on Capitol Hill on human rights violations in Afghanistan on 5/17. Speakers included Zalmay Khalilzad, Linda Cartwright \& Barnet Rubin. 
Ralph Magnus has written the chapter on Afghanistan in THE ARMED FORCES IN CONTEMPORARY SOCIETIES, edited by Edward Olsen \& Stephen Jurika, Jr., published by Westview Press, Boulder, 1985. Softcover, ca. 240 pp., $\$ 22$.

ISBN 0-8133-0160-2.

"Afghanistan: Guerre, Peche, Amitie" by Jean-Jose Pintg in the French fishing magazine CONNAISSANCE DE LA PECHE, \#81, June 1985. Puig has fished in Afghanistan every summer since the revolution.

MOSCOW RULES by Robert Moss, Villard Books, New York, 389 pp. \$16.95. From -a review in the NY Tribune: In a discussion about the objectives of the Soviet putsch in Afghanistan, we are informed that control of the country will allow the Soviets to exert greater intluence over the flow of oil from the Middle East, that it is a "perfect platform for an armoured push into Iran" and that it will scare the Pakistanis into accomodating the wishes of the Soviet Union. "This is our historic line of advance," a Soviet military authority declares. A subsequent question about how the Americans will react to this act of Soviet aggression elicits the response, "The democracies have short memories."

SUNRISE WITH SEA MONSTERS: Travels \& Discoveries 1968-1984 by Paul Theroux, Houghton Mifflin, 365 pp., \$18.95. The author says Asia begins where an Afghan accidentally shoots a hole in the roof of the bus he's riding. Afghanistan is the subject of one of the 50 essays in the book.

JEHAD-E-AFGHAN, A digest of Events \& Developments in Afghanistan, is issued monthly by the Afghan Islamic Press (AIP) in Pashto, Dari \& English. A 3month subscription is $\$ 20$ (PLS Acct. \#404, Habib Bank, Khyber Bazar, Peshawar). Moh'd Yaqub Sharafat edits the publication for AIP: P.O. Box 520, Peshawar, (See P. 2)

DEFIS is a bimonthly newsletter pub- • lished by the Bureau Int'l Afghanistan (BIA), 24 Rue de Chaligny, 75012 Paris, France. Michel Verron is the editorin-chief. Board members include Michael Barry, Gerard Chaliand Jean-Paul Gay \& Marina Isenburg. Annual subscriptions are $200 \mathrm{FF}$ payable to BIA, at BNP Reuilly, acct \#3062-50, Paris.
L'AFGHANISTAN, ISLAM ET MODERNITE POLITIQUE by Olivier Roy, Editions de Seuil, 27 rue Jacob, Paris VIe, 1985. 312 pp. ISBN 2-02-008744-8. An English language edition should be out next year.

"Consolidating the gains of the revolution" by Dmitri Pavlov in ASIA \& AFRICA TODAY, 2/85, March/April.

AFGHANISTAN: A NATION IN LOVE WITH FREEDOM by A.H. Tabibi, mentioned in the last issue, is available in the US from Igram Press, 1500 20th Street, SW, Cedar Rapids, Iowa 52404. Hardbound \$15; Softbound $\$ 10$. Add $\$ 1$ per book for shipping.

Two views on women: "Afghan Women: Unsung Heroines" by Kathleen Howard-Merriam in the CHRISTIAN SCIENCE MONITOR of 1/17:

Does the war for the liberation of the Afghan homeland mean liberation for the women? And are the women coping with new burdens? My findings are, as the example above illustrates, that the women in their own way are coping and are expressing themselves by deed and action. As one Afghan woman freedom fighter exhorted, "I would just like to mention that women and girls today play an important role in the independence struggle against communism. in our motherland."...

Reconstructive aid programs - such as income, health, and education projects capitalizing on the women's traditional handicraft skills and the development of new skills - have recently been approved by the Pakistani refugee authorities.

"Before the Revolution Women Had No Rights" by Cheryl LaBash in the 5/23 WORKER'S WORLD:

Women who have no home are given free houses. If women can and want to work, they are given jobs. Women who have lost their husbands through counter-revolutionary attacks or military actions are given their husband's pay because generally those women wish to stay with their children.

Women in Afghanistan are very. skilled in weaving. The government has opened new working places where women can develop their skills. The government gives women the thread and material to make tablecloths, bed spreads, .blouses and so on. Where before the revolution women would make detailed oriental rugs and the men would sell them in the street, now the government buys them for export. Women who devote themselves to agricultural work receive free tools, tractors, seeds and other necessities. 
"Long Term Economic Relations Between Afghanistan \& the Soviet Union: An Interpretive Study" by M.S. Noorzoy in INTERNATIONAL JOURNAL OF MIDDLE EAST STUDIES, Vol. 17, \#2, 1985. Pp. 151-173.

A schematic model of Soviet international behavior \& policies toward the LDCs is developed in the ideological-cum-political, military \& economic spheres. While the bilateral relations between Afghanistan \& Czarist Russia are traced to 1885 when Russia invaded Panjdeh, the discussion is concentrated on the different aspects of the overall relations between the two countries with the application of the above model beginning in 1917.

Some of the arguments are 1 ) that the Soviet Union as a monolithic state with multipurpose goals toward LDCs will attempt to maximize its gains in the entirety of its relations with each $L D C$, subject to constraints present. Even in the absence of the invasion the Soviets had intended this approach toward Afghanistan. The invasion has provided an open channel for this purpose and the Soviets will fail only to the extent that the mujahideen are successful. In view of mujahideen successes, the Soviets have adopted a second-best strategy of recovering as much of the cost of the war they are waging against the Afghan people from the Afghan economy. Concrete evidence from alternative sources, including Soviet trade statistics, is presented on revenue losses to Afghanistan from the sale of natural gas to the USSR \& of sales of equipment to Afghanistan during 1979-83. The losses in gas revenue from 1979-81 amount to as much as $\$ 336 \mathrm{~m}$. 2) The threat to Afghan Sovereignty from Russian expansionism was experienced not only in 1885, but was felt during the 1930s \& 1940s. 3) This article points to the similarities in Russian tactics against Afghan mujahideen \& the Muslim Freedom Fighters (so-called "Basmach") who fought the Russians from 19181933, during which Afghanistan received 200,000 refugees. This is more thoroughly discussed in another article. 4) Aside from the obvious political \& military goal, the long run goal of Soviet strategy is the economic integration of Afghanistan with its own economy. Finally, it is argued that the expansion of the economic basis of the free \& liberated areas is critical to the maintenance \& expansion of the liberation movement.

2. Newfleld says he has "no llusion that the Afghan resistance fighters can conquer the modern Soviet army." No one in Washington seems to suffer from this particular delusion either: the whole program of support for the Afghan mujahidin is $\begin{array}{ll}\text { MIDEAST } & \text { particular delusion either: the whole program of support for the Afghan mujahidin } \\ \text { UPDATE } & \text { premised on their not winning -- but tying down Soviet troops and inducing the }\end{array}$ Afghanistan. This is a maneuver against the rival superpower for relatively petty continued fron tactical advantages -- even if it means fighting to the last Afghan.

p. 23

3. Even if the Afghan insurgents won -- a most remote hypothesis, given their deep divisions, rampant localism and endless quarreling -- it is hardly clear that it would mean for Afghanistan the "expansion of freedom" that Newfield upholds. Remember that the issues which provoked their ire against the socialist government and inspired them to take up arms before the Soviet invasion were opposition to innovations like land reform, reduction of the bride price and literacy campaigns. Of course, such questions are Afghanistan's to settle, not the USSR's. But think about the effect of U.S. policy on the process:

Take a mixed bag of Afghan "moderates," tribal leaders and Islamic fundamentalists, whose opposition to Soviet occupation of their homeland commands our respect, however mingled their motives. Urge them on to a war they have no apparent chance of winning, although it causes terrible civilian suffering. Sustain them with large infusions of CIA assistance, enlarging the influence of one or another by increasing its share of the aid. Entangle them with Pakistan's autocracy. Is this a recipe for "expansion of freedom" in Afghanistan? Is it really self-determination?

Thus far the Afghan covert aid appropriations have the sort of bipartisan support that sent the Tonkin Gulf resolution sailing through the Congress. Surely there is a need for forthright acknowledgement of both the horror of Soviet intervention in Afghanistan and the growing catastrophe of U.S. intervention -- which while it may not be on a scale of the Soviet occupation is the special responsibility of the U.S. media to examine. 
-4/15 - TV stations were inaugurated in Farah \& in the Khost district of Paktia Province.

4/23 - 25 - A grand Loya Jirgah was held in Kabul. Some attendees: Moh'd Hakim from Paktia, Hellalluddin from Balkh, Abdul Samad Dehqan from Kabul, Abdulrahman Momand from Kunar, Stanekzai from Logar, Haji Abdul Rashid Kochi from Helmand, Akbar Jan Waziri from Paktika, Abdul Raouf from Nimroze, Sayed Rasul Fakor from Herat, Abdul Wahid Andiwal from Laghman \& Haji Ismatullah, a former counter-revolutionary, who told the group that the Pakistan authorities had asked him to set up a new province in Kandahar, Helmand \& Urozgan which he could govern, their objective being the disintegration of Afghanistan. (See $4 / 27,4 / 29 \& 5 / 6)$

4/27 - The Jirgah was planned to end at the time of the celebration of the $7 \mathrm{th}$ anniversary of the April 1978 Revolution. The main festivities at the Jeshyn grounds in Kabul were military parades but "hundreds of thousands of the working people staged a great \& glorious march." Babrak addressed the crowd telling the people that the recent Jirgah concluded with the participants giving their full support to the domestic \& foreign policies of the PDPA \& the DRA.

- The fire fighting school in Kabul will be elevated to the Institute for

Fire Extinguishing \& will have a residence for 315 students attached to it.

4/29 - Other Jirgah pronouncements: the enemies of Afghanistan are US imperialism, Chinese hegemonism, Pakistan \& Iran. The fraternal assistance of the USSR is necessary for repelling the brazen aggression of imperialism inside Afghanistan. Deceived Afghans are invited to return to their homeland. A letter from the Jirgah members was sent to UN Sec'y Gen'1 de Cuellar asking him to "press the imperialist forces" to stop the undeclared war against Afghanistan.

- So far over 1,332 peasant cooperatives have been established with a membership of $2 \mathrm{~m} \&$ a capital of Afs. $65 \mathrm{~m}$.

$4 / 30$ - Trade unions have a membership of 203,000. Since the Revolution workers' pay has risen $44 \%$.
5/4 - Sultan Ali Keshtmand spoke at the meeting commemorating the 40 th anniversary "of the victory of the people of the Soviet Union over Hitlerite fascism." (See 5/7\&5/9)

$5 / 6$ - The Jirgah profoundly scrutinized "the question of the political solution to the Afghan situation. The Jirgah considered the DRA peaceful proposals of $5 / 14 / 80 \& 8 / 24 / 81$ as the correct basis for the solution of all the disputable problems with Pakistan \& Iran." It - decided that a positive response should be forthcoming from both countries to end their intervention in Afghanistan. "Pakistan, by establishing over 120 military camps [See p. ...] in its territory has changed into a springboard of aggression." - The centenary of the birth of Rahmat Zakhili, Pushto poet, writer \& calligrapher, was marked.

- The anti-locust campaign is underway with Soviet-supplied pesticides.

- A 4-member delegation of the FinlandAfghan Friendship Society spent a week in Kabul.

$5 / 7$ - Babrak left for Moscow for the 40 th anniversary of the victory over fascism.

- Armed clashes between Afghan "fugitives" \& Iranians were reported in Mashed \&

Kerman. Casualties were heavy \& many Afghan-owned shops were burned.

- The executive committee of the NFF elected Ramin Atef president of the NFF. He speaks Pashto \& has a"fair knowledge" of English, Urdu.\& Arabic. He replaces Saleh Moh'd Zeary as head of the 700,000 member NFF.

5/9 - Babrak received the "Memorial Medal of the Great National War of 1941-45" in a ceremony in Moscow.

- The DRA earned $\$ 110 \mathrm{~m}$ from raisin exports \& \$26lm from grape sales last year. Foreign exchange income was $43 \%$ of the country's revenue. Agricultural production accounts for $66.4 \%$ of the national income. The Afghan GNP last year was Afs. 88.1 billion, up $8 \%$ from the previous year. - From the Bakhtar political observer: "12 Afghan \& 12 Soviet soldiers were recently captured by the Afghan counterrevolutionaries linked to the Rabbani band. They were imprisoned in a military camp located in Badaber, near Peshawar... 
" Towards the end of April, the said prisoners, in order to free themselves, resorted to a heroic action, After disarming the guardians of the camp the prisoners took control of a big depot of armaments \& ammunition of the criminal counter-revolutionaries in the camp. The prisoners requested the Pakistani government either to be returned to the DRA or be handed over to the embassies of Afghanistan \& the Soviet Union in Islamabad. Regrettably the government of Pakistan not only did not pay any attention to these rightful requests, but on the contrary, the Pakistani army took part in the attack of the counter-revolution on the camp. As a result of this unequal battle \& the hours-long exchange of fire, the heroic Afghan \& Soviet militants did not surrender. After exploding the armament depot all of them were martyred." The DRA Foreign Ministry protested to the Pakistan charge d'affaires in Kabul. (See $6 / 2$ \& p.13)

$5 / 11$ - Babrak will visit Poland later this month.

- Mahmoud Baryalai, on an official visit to Syria, met with officials of the Baath Party \& with journalists. He signed a cooperation protocol between the Baath Party \& the PDPA.

5/12 - The Bakhtar political observer: NEWSWEEK has reported that private organization of Citizens for America has decided to bring together the anti-communist guerrillas, i.e., Afghan, Kampuchean, Nicaraguan \& Angolan counter-revolutionaries who are conducting, with US help, undeclared wars against the legitimate democratic governments of their countries... Who are Reagan's Afghans? US mercenaries...sadists \& killers getting money for massacres over civilians \& sparing neither women nor children... Now they are going to be brought together for an exchange of know-how... [in a] forthcoming conference. Evidently not only the White House but the CIA is taking a favorable view of the idea. After all, shall Lewis Lehrman... head of Citizens for America pay for banditry in foreign territories out of his own pocket? ..." (See p. 7)
$5 / 12$ - "The borders of the Afghan homeland are open for all of its sons who are wandering in alien soils for one or other reason," stated Abdul Razzaq who represented the Hazara tribe at last month's Jirgah.

$5 / 13$ - Moh'd Kabir is Minister of Finance. State revenue has grown $14 \%$ over last year. $95 \%$ of the DRA's foreign aid comes from the USSR \& other socialist countries. DRA revenue comes mainly from the sale of natural gas, customs duties \& state enterprise income. (See 5/9) However tax revenues are estimated at Afs. $390 \mathrm{~m} \&$ state expenditure is Afs. 5 billion. Taxes are going up. - The FRG charge d'affaires in Kabul was handed a pote protesting the establishment by the Germans of a short-wave radio station in Pakistan which broadcasts evil propaganda.

5/14 - The DRA will pay higher prices for cotton \& sugar beets but will lower seed \& fertilizer prices. - Naim Ajmal is General Pres. of the DRA Civil Aviation Authority.

5/16 - 5/19 - Babralc Karmal, accompanied by Saleh Moh'd Zeary, Abdul Zohoor Razmjo, Sarwar Mangal. Shah Moh'd Dost, Moh'd Anwar Farzam. Ahmad Shah Sorkhabi, Lt. Gen. Shah Nawaz Tannay (DRA Armed Forces Chief of Staff) \& others paid an official \& friendly visit to Poland. In a speech at one of the official dinners, Polish leader Wojciech Jaruzelski said: "... it is not the defense of democracy \& human rights but the restoration of the barbarian yoke of slavery that the Afghan counter-revolution, supported by imperialism \& stained with brotherly blood, serves."

- In an interview in the Polish Party organ, Trybuna Ludu, Babrak described the DRA's efforts to overcome feudalism: "The elimination of feudal production relations in the villages through applying democratic land \& water reform to the interest of the peasants \& with their own participation, introduction of cooperative systems to agriculture assistance as well as procurement of agricultural machines, chemical fertilizer, improved seeds, professional services, etc., to the working peasants; creation of productiond purchase \& sale cooperatives for the toiling farmers \& nomads on volun- 
tary basis: expansion \& strengthening of the state farms \& mechanization of agriculture; development of new agricultural lands with the application of modern irrigation systems; adoption of entire measures for increasing agricultural produce \& improvement of farmers' standards of living."

5/19 - Baktar's political observer is upset over Australian Prime Minister Hayden's meeting with Burhanuddin Rabbani on a recent visit to Pakistan. The observer says the Australian government will give Rabbani \$3m "additional aid." "This money, just like that which was pocketed by Rabbani \& other leaders of the counter-revolution earlier, will serve...for their personal enrichment. The remaining 'humanitarian aid' will be spent to buy new missiles $\&$ guns for 'refugee' terrorists. The government of the DRA is coming out for a wider scale international exchange but strongly protests when Pakistani authorities use the visits of statesmen to further whip up tension in the region."

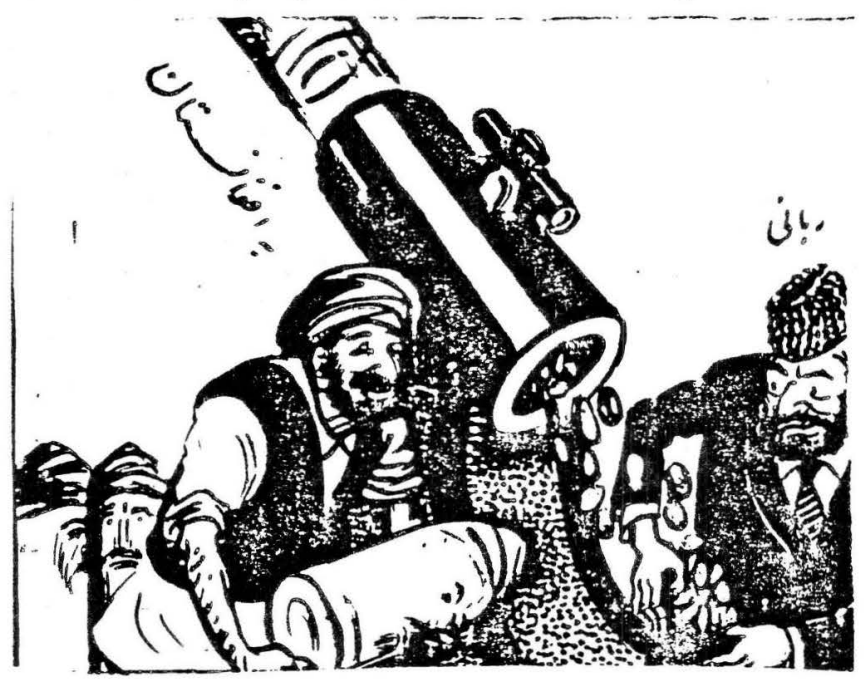

$5 / 20$ - The DRA objects to the item on the UN Economic \& Social Council's agenda about human rights in Afghanistan. The DRA says; "No violation of human rights takes place in Afghanistan that would warrant any form of investigation \& reporting."

- Ramadan began today. "In honor of this month, more consumer goods at a much cheaper price are supplied by the staterun cooperatives."

$5 / 21$ - After an overnight stop in Moscow, Babrak \& crew arrived back in Kabul after their visit to Poland. Sultan Ali Keshtmand headed the welcoming committee.
5/22 - The Presidium of the PDPA CC awarded the Medal of the April Revolution to Sultan Ali Keshtmand in a special ceremony.

$5 / 23$ - "Over 50 tons of various kinds of bread \& cookies have been added to the daily production capacity of the Kabul Central Bakery."

$5 / 25$ - The current Economic Development Plan envisages a trade circulation of over $\$ 16.7 \mathrm{~m}-\$ 7 \mathrm{~m}$ in export \& $\$ 9 \mathrm{~m}$ in import. - Over I.Im karakul pelts were offered on the Leningrad, London \& Leipzig markets last year. The main purchasers are the FRG, Italy, France \& the USA. Pelt exporters will recelve an additional 10\% bonus this year.

$5 / 26$ - A Swiss company will sell the DRA equignent for the Khair-Khana thermopower generator for SF 71,070,000. Swiss engineers will supervise the project. - With the completion of the remodeling of the Kabul airport in 5 years, "big military, transport \& passenger planes can take fuel from Kabul airport in case of need which may arise while over flying the air space of Afghanistan."

- Trade figures during the last Afghan year were export, $\$ 778 \mathrm{~m}$; import, $\$ 902 \mathrm{~m}$. According to the Commerce Ministry, the USSR's share in Afghan trade is "more than 50\%."

5/27 - The DRA Lawyers' Assn。 condemned the forthcoming trial in Italy of Sergei Antonov, a Bulgarian airline employee accused of being involved in the assassination attempt on the Pope.

- The 66th anniversary of the establishment of diplomatic relations between the USSR \& Afghanistan was marked.

$5 / 28$ - Physical education classes have been introduced in all the faculties of Kabul University.

- Karina Keshtmand is head of the DRA Dept. of Kindergartens. There are 105 kindergartens in the DRA - 81 in Kabul serving 11,000 children \& 24 in the provinces serving ca. 900 children.

- Shah Moh'd Dost met with UN rep. Diego Cordovez to discuss possibile solutions for the Afghan issue.

5/29 - Bandits in Zabul Province along with their leader Maulavi Habibullah were exterminated \& a large number of weapons, including 30 Chinese missiles, were captured.

5/30 - Babrak met with Diego Cordovez. 
6/2 - The Haj subsidy this year will be Afs. 172m.

- From the Bakhtar political observer:

"An eye-witness account of events in

Badaber Camp in Pakistani territory, where Soviet \& Afghan servicemen were killed after being abducted by counterrevolutionary bandits in DRA \& smuggled into Pakistan, has once again revealed the shameless lies of the military, regime of Islamabad... Moh'd Shah, a former worker with a Kabul car \& truck service center who was a prisoner at the Badaber Camp, said that he saw Russian prisoners there several times. On the night of April 26-27 a handful of Soviet \& Afghan servicemen held at the camp managed to disarm the guards \& seize a military hardware depot. They set all the other prisoners, including Moh'd Shah, free. Moh'd Shah further added that he heard a shoot-out in the camp \& then the booms of heavy guns. That was Pakistani troops using artillery to shoot at the defending Russians \& Afghans point blank. The battle was unequal $\&$ all the defending Russian \& Afghan troops perished."

$6 / 3$ - The USSR will help the DRA set up 2 new mechanized agricultural stations. There are 5 such stations currently operating in the DRA.

- A 40-bed Ob-Gyn annex was opened in the Malalai Maternity Hospital in Kabul. The annex costs came from the State budget (Afs. 7m) \& WHO ( $\$ 35 \mathrm{~m}$ ).

- The number of personnel in the Ministry of Islamic Affairs jumped from 5,489 to 12,419 this year. The figure includes 11,570 preachers \& mosque workers.

$6 / 4$ - Over $1 \frac{1}{2}$ m people have become literate since the Saur Revolution.

- New appointments:

Hajibullah Masir - Minister of Mines \& Industries.

Abdul Basir Ranjbar - Gen'1 Pres. of Da Afghanistan Bank

Moh'd Daud Kawyan - President of Bakhtar Information Agency

- Bakhtar waxes literary:

"On that day the children of the Chaqma Quli village in Samangan did not go to school. The women \& girls were watching what was happening from behind the corners of their houses. The peasants, holding spades on their shoulders, were standing in the square. Grand festival was held in the village. On that day the peasants were to become land-owners. O1d Baba Tora was also standing among the peasants. On such occasions he was glad that he had been born a tall man because he could properly observe the happenings even being quite far from the center. The peasants received, one after another, papers, precious sheets - land-ownership documents. A young peasant who had just received a document suddenly started running somewhere, It looked as though he had lost control over himself. He kept running to the graveyard of the village \& stopped beside a grave. "Father! Get up! I received land. See, I have brought the land deed." But the joy of the people who after years of yearning $\&$ dreaming of land \& their desire fulfilled, was interrupted after a while. The situation in Chaqma Quli changed. The counter-revolution had penetrated into the village \& creating panic persuaded the villagers to join them. The bandits said: "It is unlawful that you have received land, Islam is in danger." These words strongly influenced the dark mind of Baba Tora \& under their pressure he joined their ranks \& left for the mountains. Some time later, the only school of the village was set on fire. This fact awoke some uneasiness in Baba Tora, as though unknown danger was forthcoming. The other day the preacher of the village mosque was martyred. On the other hand he knew that the peasant's cooperative was set up in their village \& the peasants who had received land were enrolled in their cooperative. The cooperative gives them loans, chemical fertilizer \& seeds. The peasants who were wandering for a loaf of bread till yesterday are now harvesting the yields of their own land. It seemed as though Baba Tora was placed on the wrong side of the mountain. It went on like this until Baba Tora was informed that another group of bandits had plundered his household \& took away his daughter-in-law.... Baba Tora held talks with Mullah Beg, the ringleader of the group, who, while talking to Baba Tora was getting pale. Sometimes a vague smile was appearing on his face as he listened to Baba Tora's doubts. Mullah Beg, remembering his spouse \& children, was homesick... The next day the provincial daily issued a news item: A 10-man group led by Mullah Beg who had been previously deceived, availed themselves of the general amnesty decree \& returned to their homes. Baba Tora has gradually got a good fame as a militant defender of the revolution..." 


\section{Centres for Training Afghan Counter-Revolutionaries in Pakistan}

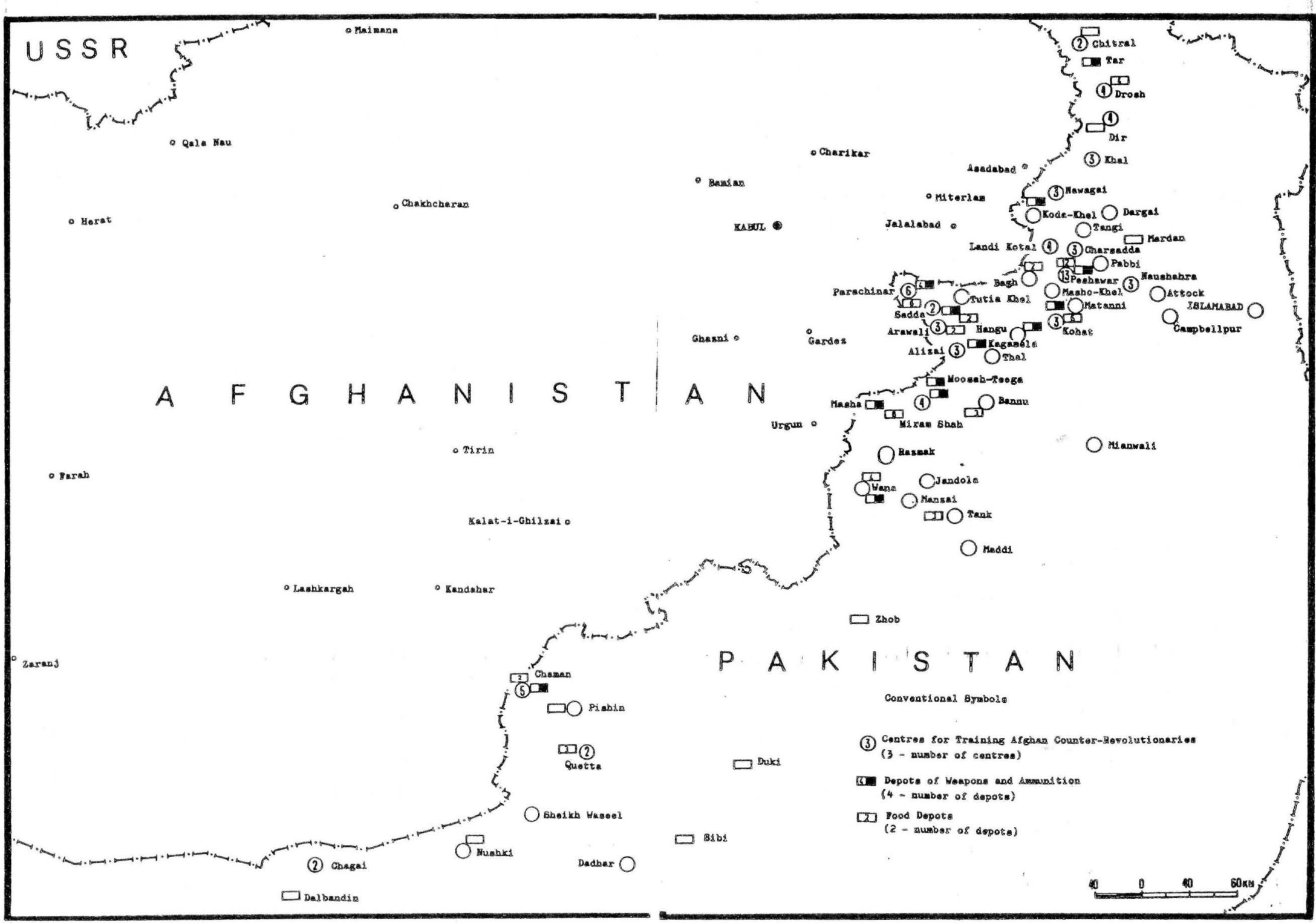




\section{Centres for Training Afghan Counter-Revolutionaries in Pakistan}

\begin{tabular}{|c|c|c|c|c|}
\hline No & L Location' & $\begin{array}{l}\text { Brief } \\
\text { description } \\
\text { of the centre }\end{array}$ & $\begin{array}{l}\text { Organization } \\
\text { responsible }\end{array}$ & $\begin{array}{c}\text { Date of } \\
\text { setting up }\end{array}$ \\
\hline 1 & Chitral & $\begin{array}{l}\text { A centre for general military } \\
\text { training, for } 300\end{array}$ & ISA & 1980 \\
\hline 2 & $\begin{array}{l}\text { Chitral } \\
(3 \mathrm{~km} \\
\text { north) }\end{array}$ & $\begin{array}{l}\text { A centre for training in } \\
\text { firing mortars and anti-tank } \\
\text { weapons. for } 100 \text {. Term of } \\
\text { training up to } 3 \text { months }\end{array}$ & ISA & 1980 \\
\hline 3 & Drosh & $\begin{array}{l}\text { A centre for general military } \\
\text { training at a refugee camp. } \\
\text { for } 600\end{array}$ & NLFA & $\begin{array}{l}\text { September } \\
1981\end{array}$ \\
\hline 4 & $\begin{array}{l}\text { Drosh } \\
\text { ( } 4 \mathrm{~km} \\
\text { south- } \\
\text { west) }\end{array}$ & $\begin{array}{l}\text { A centre for general military } \\
\text { training, for } 200\end{array}$ & IPA & $\begin{array}{l}\text { September } \\
1981\end{array}$ \\
\hline 5 & $\begin{array}{l}\text { Gahirat } \\
\text { (10 km } \\
\text { north of } \\
\text { Drosh) }\end{array}$ & $\begin{array}{l}\text { A centre for general military } \\
\text { training, for } 100\end{array}$ & & 1981 \\
\hline 6 & $\begin{array}{l}\text { Mirkhani } \\
(12 \mathrm{~km} \\
\text { south-west } \\
\text { of Drosh })\end{array}$ & $\begin{array}{l}\text { A centre for general military } \\
\text { training, for } 600\end{array}$ & & $\begin{array}{l}\text { June } \\
1979\end{array}$ \\
\hline 7 & $\begin{array}{l}\text { Dir } \\
\text { (southern } \\
\text { outskirts) }\end{array}$ & $\begin{array}{l}\text { A centre for general and } \\
\text { special military training } \\
\text { (mining and demolition). } \\
\text { for } 600 \text {. Term of training up } \\
\text { to } 6 \text { months }\end{array}$ & NIFA & $\begin{array}{l}\text { September } \\
1981\end{array}$ \\
\hline 8 & $\begin{array}{l}\text { Dir } \\
\text { (15 km } \\
\text { west) }\end{array}$ & $\begin{array}{l}\text { A centre for training sab- } \\
\text { otage and terrorist groups }\end{array}$ & NLFA & $\begin{array}{l}\text { September } \\
1981\end{array}$ \\
\hline 9 & $\begin{array}{l}\text { Dir } \\
\text { (14 km } \\
\text { south-east) }\end{array}$ & $\begin{array}{l}\text { A centre for general military } \\
\text { training and training in } \\
\text { handling mortars and anti- } \\
\text { tank weapons }\end{array}$ & IRMA & \\
\hline & $\begin{array}{l}\text { Barwa } \\
\text { ( } 25 \mathrm{~km} \\
\text { south-west } \\
\text { of Dir) }\end{array}$ & $\begin{array}{l}\text { A centre for training groups } \\
\text { of saboteurs and terrorists. } \\
\text { for } 400\end{array}$ & 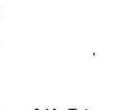 & $\begin{array}{c}\text { August } \\
1981\end{array}$ \\
\hline & Khal & $\begin{array}{l}\text { A centre for general military } \\
\text { training, for } 200 \text {. Includes } \\
\text { one group for training } \\
\text { grenade launcher oper- } \\
\text { ators. Term of training up to } \\
3 \text { months }\end{array}$ & NLFA & $\begin{array}{l}\text { March } \\
1982\end{array}$ \\
\hline & $\begin{array}{l}2 \text { Moonda- } \\
\text { Kala } \\
(20 \mathrm{~km} \\
\text { north-east } \\
\text { of Khal) }\end{array}$ & $\begin{array}{l}\text { A centre for general military } \\
\text { and special training } \\
\text { (groups of grenade } \\
\text { launcher operators and } \\
\text { demolition men), for } 200\end{array}$ & & \\
\hline & $\begin{array}{l}3 \text { Ormara } \\
\text { ( } 5 \mathrm{~km} \text { west } \\
\text { of Khal) }\end{array}$ & $\begin{array}{l}\text { A centre for general military } \\
\text { training. for } 200 \text {. Has a } \\
\text { depot of weapons and am- } \\
\text { munition }\end{array}$ & ISA & $\begin{array}{l}\text { February } \\
1984\end{array}$ \\
\hline & 4 Nawagai & $\begin{array}{l}\text { A centre for special military } \\
\text { training (groups of grenade } \\
\text { launcher operators and AA } \\
\text { gunners), for } 150\end{array}$ & & 1980 \\
\hline & $\begin{array}{l}\text { Moham- } \\
\text { madgart } \\
\text { ( } 2 \mathrm{~km} \text { south } \\
\text { of } \\
\text { Nawagai) }\end{array}$ & $\begin{array}{l}\text { A centre for special mil- } \\
\text { itary training (combat } \\
\text { use of mortars and anti- } \\
\text { tank and anti-aircraft } \\
\text { guns), for } 500 \text {. Instructors } \\
\text { are former Afghan army } \\
\text { officers and foreign } \\
\text { specialisis. There is a train. } \\
\text { ing regiment at the centre. } \\
\text { There are US, Chinese and } \\
\text { Egyptian advisers }\end{array}$ & (1) & 1982 \\
\hline & $\begin{array}{l}\text { Ahkarzai- } \\
\text { Dag } \\
\text { ( } 10 \mathrm{~km} \\
\text { south of } \\
\text { Nawagai) }\end{array}$ & $\begin{array}{l}\text { A centre for general military } \\
\text { training. for } 200\end{array}$ & & $\begin{array}{l}\text { June } \\
1978\end{array}$ \\
\hline & $\begin{array}{l}\text { Dargai } \\
\text { (one km } \\
\text { north- } \\
\text { west) }\end{array}$ & $\begin{array}{l}\text { A centre for general military } \\
\text { training. for } 250\end{array}$ & $\begin{array}{l}\text { ISA, } \\
\text { IRMA }\end{array}$ & \\
\hline
\end{tabular}

'The location of the training centres is given in the direction fram the north to the south of Pakistan.

\section{No Location}

\begin{tabular}{|c|c|c|c|}
\hline 18Tangi & $\begin{array}{l}\text { A centre for special military } \\
\text { training (combat use of } \\
\text { mortars, anti-tank and AA } \\
\text { guns), for } 900 \text {. Instructors } \\
\text { are Pakistani servicemen }\end{array}$ & IPA & 1983 \\
\hline $\begin{array}{c}19 \text { Koda- } \\
\text { Khel }\end{array}$ & $\begin{array}{l}\text { A centre for general military } \\
\text { training. for } 100\end{array}$ & & 1983 \\
\hline $\begin{array}{r}20 \text { Char- } \\
\text { sadda }\end{array}$ & $\begin{array}{l}\text { A centre for general military } \\
\text { training, for } 150\end{array}$ & IPA & 1981 \\
\hline $\begin{array}{l}21 \text { Char- } \\
\text { sadda }\end{array}$ & $\begin{array}{l}\text { A centre for general military } \\
\text { training. for } 200\end{array}$ & ISA & 1982 \\
\hline $\begin{array}{l}22 \text { Shab- } \\
\text { gadar } \\
\text { ( } 20 \mathrm{~km} \\
\text { north-west } \\
\text { of } \text {. } \\
\text { Charsadda) }\end{array}$ & $\begin{array}{l}\text { A centre for general military } \\
\text { training, for } 100 \text {. There is a } \\
\text { group for training sabo- } \\
\text { teurs. Instluctors are } \\
\text { Chinese specialists }\end{array}$ & ISA & 1983 \\
\hline
\end{tabular}

\section{Landi}

A centre for general military training. for 300 , at a re.

IPA

1981

24 Torafugee camp

Teega specialists in combat use of $(5 \mathrm{~km}$ north anti-tank weapons, for 80 of Landi Kotal)

25 KhonakiKila $(15 \mathrm{~km}$ $\mathrm{km}$ training (combat use of north-east and grenade launchers of Landi guns), for 100

Kotal)

26 Lowaramena $12 \mathrm{~km}$
north-east north-east
of Landi of Landi
Kotal)

A centre for special military training (mining itary training (mining and demolition, antitank and AA weapons), for
300 . Instructors are
American and Chinese specialists

$27 \mathrm{Bagh}$

A centre for general military training. for 150

IPA

1983

$\begin{array}{cl}28 \text { Warsak } & \text { A centre for training } \\ \text { (30 km } & \text { specialists in combat use of } \\ \text { north-west } & \text { AA weapons, including the } \\ \text { of } & \text { Arrow-2M portable AA } \\ \text { Peshawar) } & \text { rocket launching unit and } \\ & \text { rocket launchers, for } 700 . \\ & \text { Term of training from } 3 \text { to } \\ & \text { months. Instructors are } \\ & \text { American and Egyptian }\end{array}$

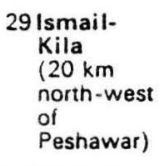

30 Michni

Fort

$(22 \mathrm{~km}$ north-west of

Peshawar)

31 KachaGarhi $110 \mathrm{~km}$ north-west of Pesha. war)

\section{Pesha.} war-1 specialists

A centre for training in firing mortars, hand anti-tank grenade launchers and small arms, for 200. Term of training from 3 to 6 months A centre for training in firing automatic weapons and hand anti-tank grena. de launchers, for 70 . Term of training from 2 to 3 months

A centre for general military raining of rebels at the Naserbagh refugee camp. There is a group for training in mining and demolition. Instructors are Pakistanis

A centre for training specialists in combat use of various weapons. Located in the city near the Firdausi Cinema. Instructors are Chinese specialists
IUMA $\begin{gathered}\text { August } \\ 1984\end{gathered}$

IPA $\begin{gathered}\text { March } \\ 1984\end{gathered}$

September
1979

IPA, December

NIFA 1979

NLFA

IPA,

IRMA

\section{Note}

The following abbreviations of Afghan counter-revolutionary yruupmysure

used in the table:

IP-the Islamic Party of Afghan

Fighters for the Faith

NIFA

IPA-the Islamic Party of Afghanistan ISA-the Islamic Society of Afghanisian NLFA-the National Liberation Front of Afghanistan

NIFA-the National Islamic Front of Afghanistan

IUMA - the Isiamic Unity of

Mujaheddins of Afghanistan

IRMA-- the Islamic Revolutionary Movement of Afghanistan 


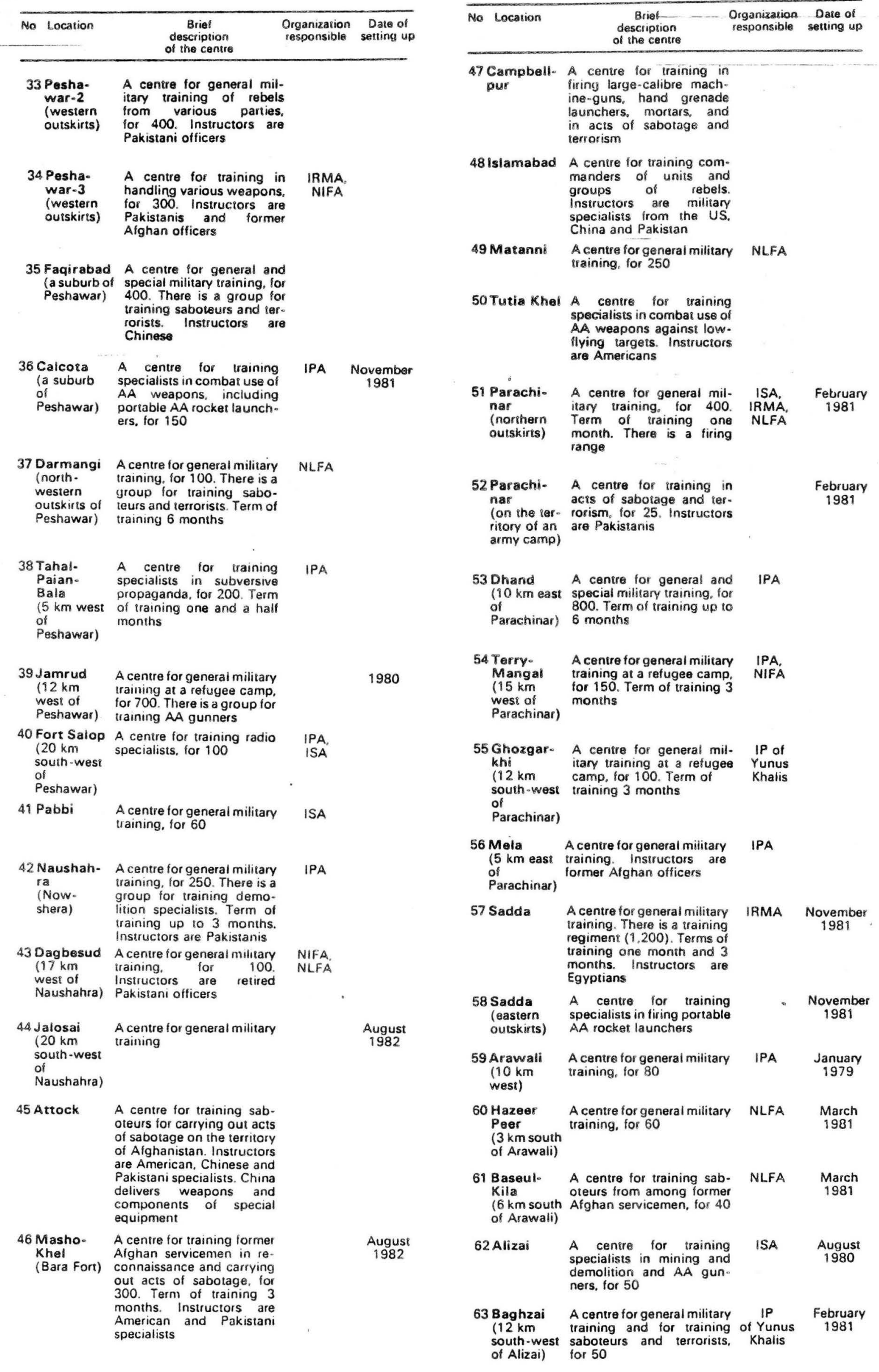




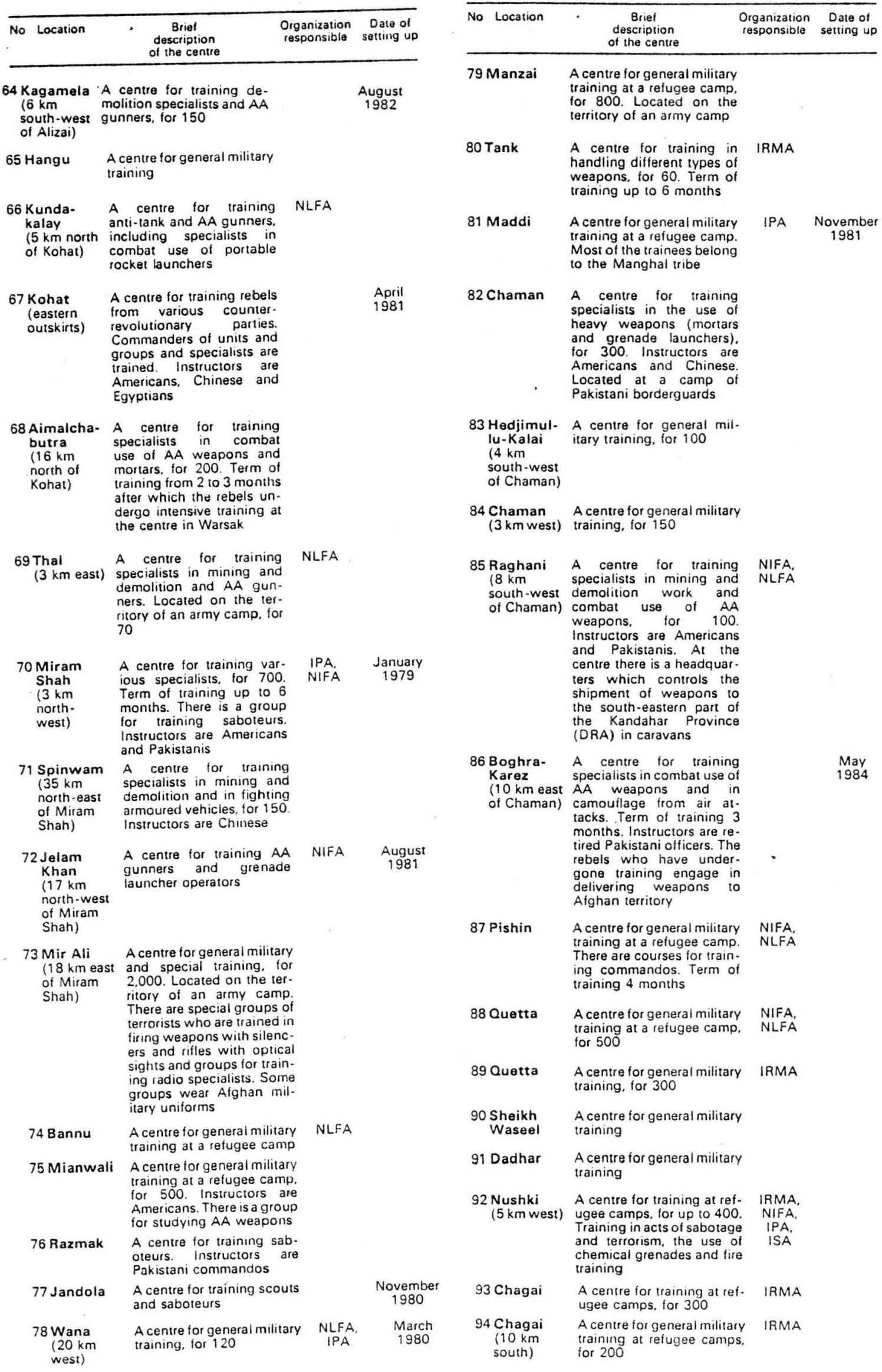


1985

sutr :هوب:

AUGUST

14.0

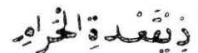

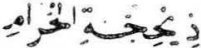

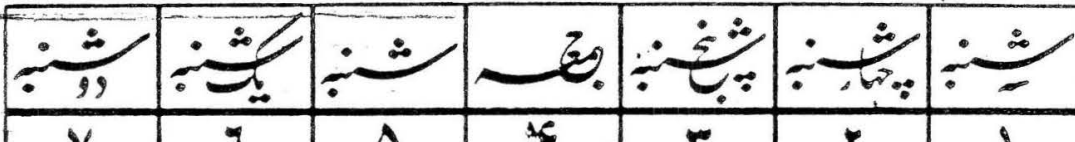

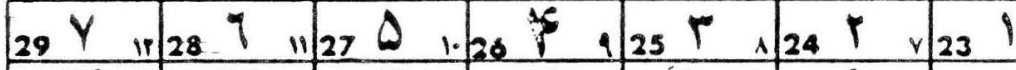

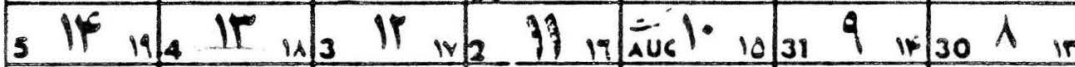

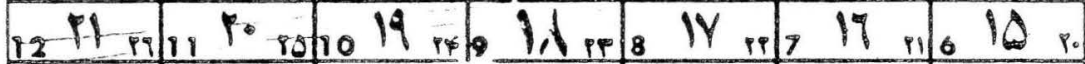

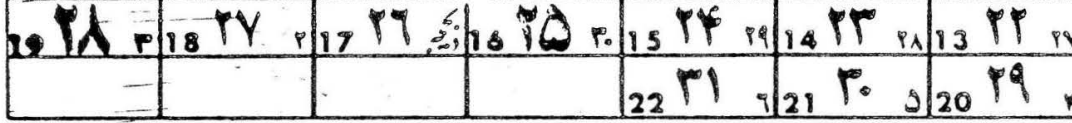

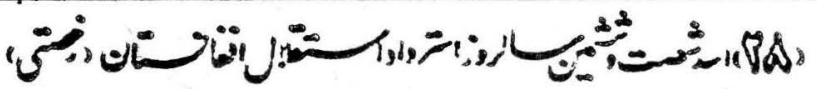

1985 incust

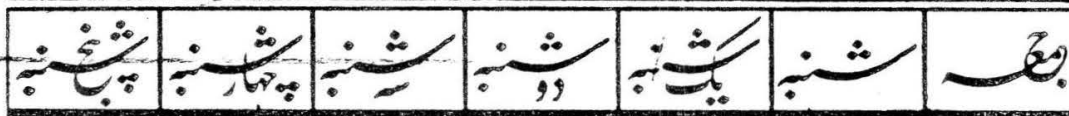

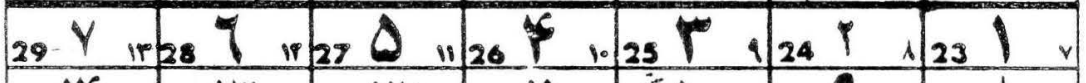

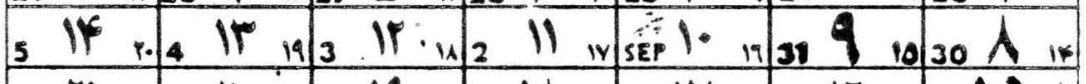

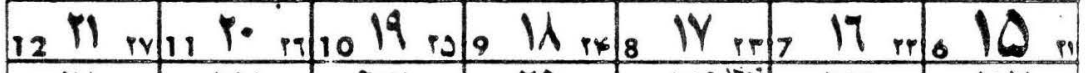

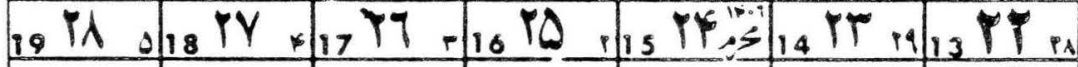

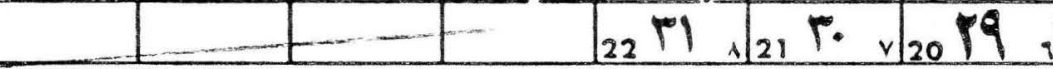

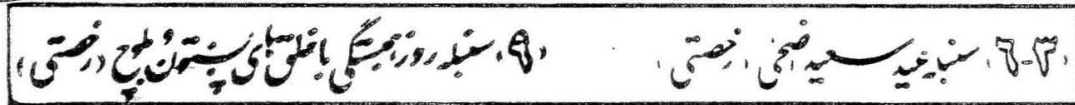

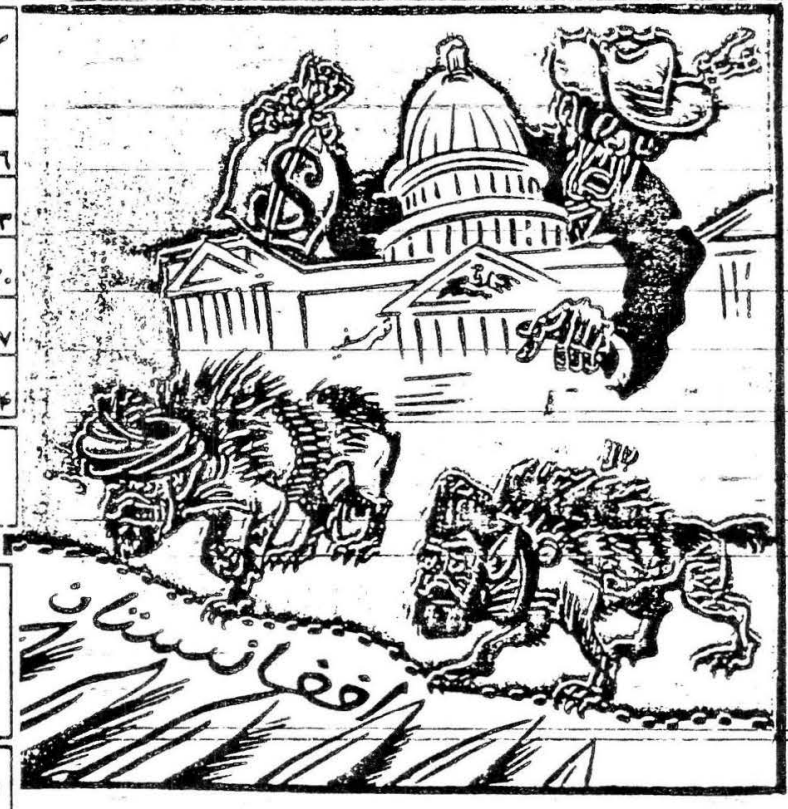

Reagan to-Gulbuddin \& Rabbani:

"Stop fighting each other \& get on with it."

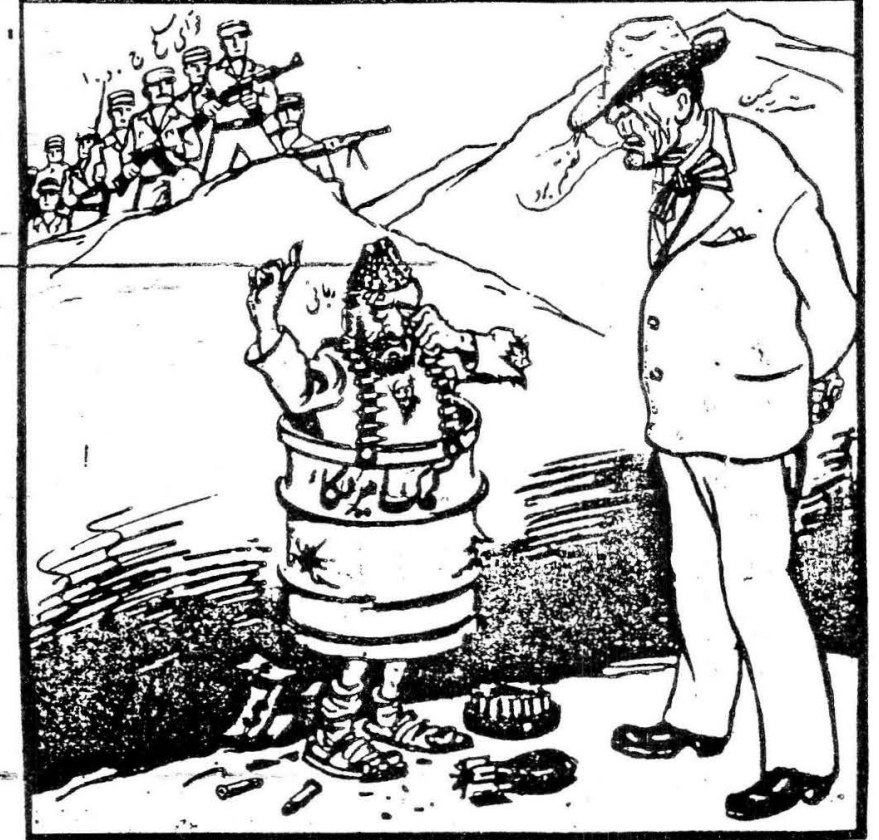

Raubaui to Reagan: "If you're so brave, you go fight."

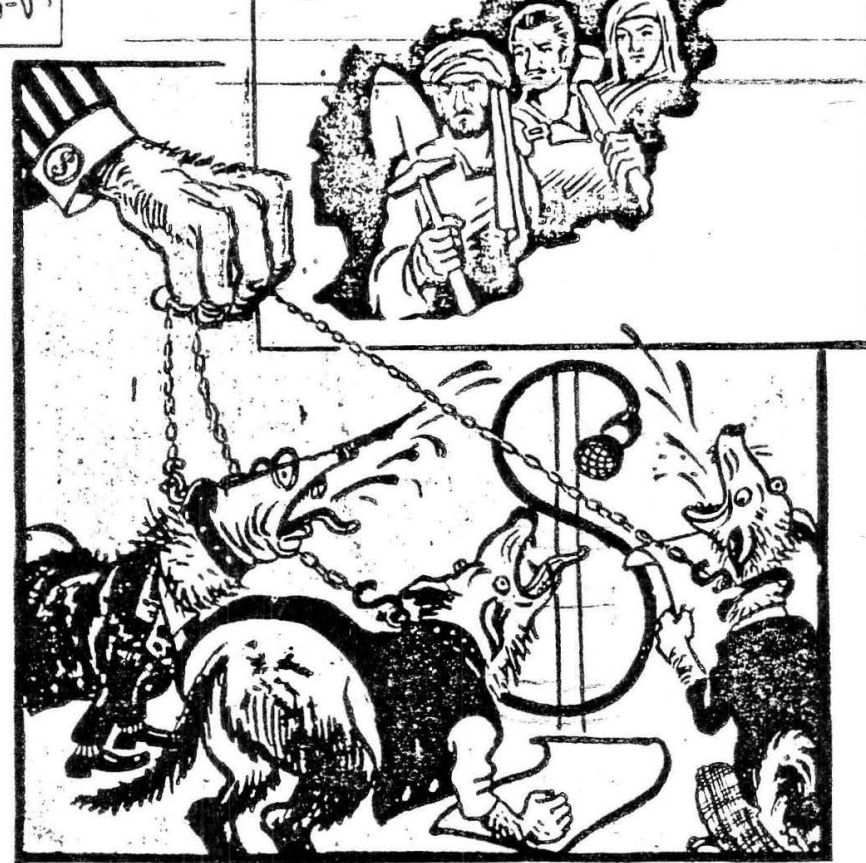

The leashed-dogs of imperialist media. 